\title{
Impact of January 2005 solar proton events on chlorine species
}

\author{
A. Damiani ${ }^{1}$, B. Funke ${ }^{2}$, D. R. Marsh ${ }^{3}$, M. López-Puertas ${ }^{2}$, M. L. Santee ${ }^{4}$, L. Froidevaux ${ }^{4}$, S. Wang ${ }^{4}$, C. H. Jackman ${ }^{5}$, \\ T. von Clarmann ${ }^{6}$, A. Gardini ${ }^{2}$, R. R. Cordero ${ }^{1}$, and M. Storini ${ }^{7}$ \\ ${ }^{1}$ Physics Department, University of Santiago de Chile, Santiago, Chile \\ ${ }^{2}$ Instituto de Astrofísica de Andalucía, CSIC, Granada, Spain \\ ${ }^{3}$ National Center for Atmospheric Research, Boulder, Colorado, USA \\ ${ }^{4}$ Jet Propulsion Laboratory, California Institute of Technology, Pasadena, California, USA \\ ${ }^{5}$ NASA Goddard Space Flight Center, Greenbelt, Maryland, USA \\ ${ }^{6}$ Karlsruhe Institute of Technology, Institute for Meteorology and Climate Research, Karlsruhe, Germany \\ ${ }^{7}$ Institute of Interplanetary Space Physics, INAF, Rome, Italy
}

Correspondence to: A. Damiani (alessandro.damiani@usach.cl)

Received: 5 November 2011 - Published in Atmos. Chem. Phys. Discuss.: 20 January 2012

Revised: 11 April 2012 - Accepted: 12 April 2012 - Published: 10 May 2012

\begin{abstract}
Sudden changes in stratospheric chlorine species in the polar northern atmosphere, caused by the Solar Proton Events (SPEs) of 17 and 20 January 2005, have been investigated and compared with version 4 of the Whole Atmosphere Community Climate Model (WACCM4). We used Aura Microwave Limb Sounder (MLS) measurements to monitor the variability of $\mathrm{ClO}, \mathrm{HCl}, \mathrm{HOCl}$ and Michelson Interferometer for Passive Atmospheric Sounder (MIPAS) on ENVISAT to retrieve $\mathrm{ClONO}_{2}$. SPE-induced chlorine activation has been identified. $\mathrm{HCl}$ decrease occurred at nearly all the investigated altitudes (i.e., $10-0.5 \mathrm{hPa}$ ) with the strongest decrease (of about $0.25 \mathrm{ppbv}$ ) on 21 January. $\mathrm{HOCl}$ was found to be the main active chlorine species under nighttime conditions (with increases of more than $0.2 \mathrm{ppbv}$ ) whereas both $\mathrm{HOCl}$ and $\mathrm{ClO}$ enhancements (about $0.1 \mathrm{ppbv}$ ) have been observed at the polar night terminator. Further, small $\mathrm{ClO}$ decreases (of less than $0.1 \mathrm{ppbv}$ ) and $\mathrm{ClONO}_{2}$ enhancements (about $0.2 \mathrm{ppbv}$ ) have been observed at higher latitudes (i.e., at nighttime) roughly above $2 \mathrm{hPa}$.

While WACCM4 reproduces most of the SPE-induced variability in the chlorine species fairly well, in some particular regions discrepancies between the modeled and measured temporal evolution of the abundances of chlorine species were found. $\mathrm{HOCl}$ changes are modelled very well with respect to both magnitude and geographic distribution. $\mathrm{ClO}$ decreases are reproduced at high latitudes, whereas $\mathrm{ClO}$ enhancements in the terminator region are underestimated and attributed to background variations. WACCM4 also re-
\end{abstract}

produces the $\mathrm{HCl}$ depletion in the mesosphere but it does not show the observed decrease below about $2 \mathrm{hPa}$. Finally, WACCM4 simulations indicate that the observed $\mathrm{ClONO}_{2}$ increase is dominated by background variability, although SPE-induced production might contribute by $0.1 \mathrm{ppbv}$.

\section{Introduction}

Since the early seventies it is known that energetic solar protons are able to affect the neutral chemical components of the polar atmosphere, such as $\left[\mathrm{NO}_{\mathrm{x}}\right]=[\mathrm{NO}]+\left[\mathrm{NO}_{2}\right]$ and $\left[\mathrm{HO}_{\mathrm{x}}\right]=[\mathrm{H}]+[\mathrm{OH}]+\left[\mathrm{HO}_{2}\right]$ via ion chemical reactions (e.g., Swider and Keneshea, 1973; Crutzen et al., 1975; Solomon et al., 1981). These phenomena are important because the $\mathrm{NO}_{\mathrm{x}}$ and $\mathrm{HO}_{\mathrm{x}}$ enhancements lead to efficient catalytic cycles of ozone destruction. The short chemical lifetime of mesospheric hydroxyl $(\mathrm{OH})$ radicals causes a relatively brief atmospheric impact from the increased $\mathrm{HO}_{\mathrm{x}}$ during Solar Proton Events (SPEs) (e.g., Damiani et al., 2010a). A short term ozone depletion occurs from the enhanced SPEproduced $\mathrm{HO}_{\mathrm{x}}$, followed by a fast recovery. On the other hand, the longer chemical lifetime of $\mathrm{NO}_{\mathrm{x}}$, in particular during the polar winters (when photolysis does not occur), can cause noticeable ozone depletion in the upper stratosphere lasting up to several months (e.g., Randall et al., 2005; Jackman et al., 2009). For this reason, previous efforts have been mainly focussed on this important relationship (i.e., $\mathrm{NO}_{\mathrm{x}}$ vs. 
$\mathrm{O}_{3}$ ). Recently, thanks to new satellite observations, many studies have dealt with the impact of SPEs (e.g., Jackman et al., 2005; Rohen et al., 2005; Semeniuk et al., 2005; Egorova et al., 2011), in particular the so-called Halloween SPE of October-November 2003, on other chemical components (e.g., $\mathrm{HNO}_{3}, \mathrm{~N}_{2} \mathrm{O}_{5}, \mathrm{ClONO}_{2}$ ) (e.g., López-Puertas et al., 2005a,b; Funke et al., 2011). The variability of chlorine species is a further interesting consequence of solar protons entering the Earth's atmosphere. This has been investigated only in a few studies (i.e., Solomon and Crutzen, 1981; von Clarmann et al., 2005; Winkler et al., 2009) but none of these reported on variations in all the main components (i.e., $\mathrm{HCl}$, $\mathrm{ClONO}_{2}, \mathrm{ClO}$ and $\mathrm{HOCl}$ ) of the chlorine family during a single SPE. This is an essential condition to correctly analyse SPE effects.

Hydrogen chloride $(\mathrm{HCl})$ and chlorine monoxide $(\mathrm{ClO})$ are the main contributors to the $\mathrm{Cl}_{\mathrm{y}}$ family $\left(\left[\mathrm{Cl}_{\mathrm{y}}\right]=[\mathrm{Cl}]+\right.$ $[\mathrm{ClO}]+[\mathrm{HCl}]+\left[\mathrm{ClONO}_{2}\right]+\left[2 \mathrm{Cl}_{2} \mathrm{O}_{2}\right]+[\mathrm{HOCl}]+[\mathrm{OClO}]+$ $\left.[\mathrm{BrCl}]+\left[2 \mathrm{Cl}_{2}\right]\right) . \mathrm{HCl}$ is the most important stratospheric reservoir species for $\mathrm{Cl}$. $\mathrm{ClO}$ carries most of the reactive chlorine in the stratosphere during daytime. Their monitoring is very important since both gases can be considered a significant indicator of the effectiveness of the Montreal protocol agreement (e.g., Froidevaux et al., 2006; Jones et al., 2011). On the other hand, a significant interplay between $\mathrm{NO}_{\mathrm{x}}$ and $\mathrm{ClO}_{\mathrm{x}}$ is provided by $\mathrm{ClONO}_{2}$, which is another important reservoir species. Also hypochlorous acid $(\mathrm{HOCl})$ has remarkable importance for its catalytic cycle of mid-latitude lower stratospheric ozone loss (Lary, 1997), and because it acts as a link between chlorine and $\mathrm{HO}_{\mathrm{x}}$ chemistry. However, very few $\mathrm{HOCl}$ observations from satellites have been available until recently. The reason for this is twofold. First, this is due to the fact that $\mathrm{HOCl}$ is not a very useful indicator of the atmospheric chlorine content from human made CFCs; second, there is also a technical difficulty due to the weak nature of $\mathrm{HOCl}$ transitions in the microwave/millimeter wave region and in the infrared windows, and the low concentration of $\mathrm{HOCl}$ and low signal/noise ratio.

In the upper stratosphere, the chlorine catalytic cycles of ozone destruction have the greatest efficiency around $40 \mathrm{~km}$ (Lary, 1997), where SPE-induced changes of chlorine species are expected. There, they can contribute to the short-term $\mathrm{O}_{3}$ depletion occurring after a SPE (von Clarmann et al., 2005), which is principally caused by enhanced $\mathrm{NO}_{\mathrm{x}}$ and $\mathrm{HO}_{\mathrm{x}}$. In this regard, Salmi et al. (2011) have found that, although not connected to SPEs, the ozone decrease of late February 2009 occurring at polar northern latitudes between about 30 and $50 \mathrm{~km}$, was due to activation of halogen chemistry. Although SPE-induced changes of chlorine species are expected to have an impact only on the short-timescale SPEinduced $\mathrm{O}_{3}$ variability, the study of chlorine changes could be useful to validate chemical schemes in current models.

The influence of SPEs on the chlorine family is indirect and it occurs via the increase of $\mathrm{HO}_{\mathrm{x}}$ and $\mathrm{NO}_{\mathrm{x}}$. SPE-induced enhancement in $\mathrm{HO}_{\mathrm{x}}$ is the main factor leading to chlorine changes. Indeed, in prior studies (e.g., von Clarmann et al., 2005; Damiani et al., 2009) chlorine variations, recorded under SPE conditions, were used as a proxy of $\mathrm{HO}_{\mathrm{x}}$ changes. Moreover SPE-induced enhancement in $\mathrm{NO}_{\mathrm{x}}$ is important with respect to $\mathrm{ClONO}_{2}$. The pioneering work of Solomon and Crutzen (1981) proposed several chemical mechanisms to explain the impact of the SPE of August 1972 on polar atmospheric composition. Two reactions included in those schemes relevant to this study are:

$\mathrm{ClO}+\mathrm{NO}_{2}+\mathrm{M} \rightarrow \mathrm{ClONO}_{2}+\mathrm{M}$

and

$\mathrm{HCl}+\mathrm{OH} \rightarrow \mathrm{Cl}+\mathrm{H}_{2} \mathrm{O}$.

The first experimental confirmation (by satellite data) of the importance of Reaction (R1) under SPE conditions was reported by López-Puertas et al. (2005a) and von Clarmann et al. (2005). The former examined the $\mathrm{ClONO}_{2}$ in the context of $\mathrm{NO}_{\mathrm{y}}$ components (i.e., $\mathrm{HNO}_{3}, \mathrm{~N}_{2} \mathrm{O}_{5}, \mathrm{ClONO}_{2}$ and $\mathrm{NO}_{\mathrm{x}}$ ), whereas the latter in the context of chlorine species (i.e., $\mathrm{ClO}, \mathrm{HOCl}, \mathrm{ClONO}_{2}$ ). In both works, data from Michelson Interferometer for Passive Atmospheric Sounder (MIPAS), recorded during the 2003 Halloween storm, were used. In particular, von Clarmann et al. (2005) showed an enhancement of $\mathrm{ClO}$ and $\mathrm{HOCl}$ immediately after the SPE, which was interpreted as being due to the fast reaction:

$\mathrm{Cl}+\mathrm{O}_{3} \rightarrow \mathrm{ClO}+\mathrm{O}_{2}$

(with $\mathrm{Cl}$ arising from Reaction $\mathrm{R} 2$ ), and a subsequent $\mathrm{HOCl}$ formation by:

$\mathrm{ClO}+\mathrm{HO}_{2} \rightarrow \mathrm{HOCl}+\mathrm{O}_{2}$.

In this context a key role is played by $\mathrm{HO}_{2}$. The SPE-induced $\mathrm{HO}_{2}$ enhancement may lead to a shift of the balance between $\mathrm{ClO}$ and $\mathrm{HOCl}$ towards the latter, so, particularly under nighttime conditions, a decrease of $\mathrm{ClO}$ could also occur (Funke et al., 2011).

There is still a further important pathway which can significantly reduce the $\mathrm{ClO} / \mathrm{HCl}$ ratio in the upper stratosphere and, hence, the sensitivity of ozone to chlorine:

$\mathrm{ClO}+\mathrm{OH} \rightarrow \mathrm{HCl}+\mathrm{O}_{2}$.

Indeed, although the major products of the $\mathrm{OH}+\mathrm{ClO}$ reaction are the active $\mathrm{HO}_{2}$ and $\mathrm{Cl}$ radicals, even a small branching ratio may lead to less ozone depletion by chlorine species since Reaction (R5), faster than Reaction (R2), converts an active form $(\mathrm{ClO})$ into a stable reservoir species $(\mathrm{HCl})$ (e.g., Lipson et al., 1997).

Some preliminary confirmation of the relevant role of Reaction (R2) has been shown by Damiani et al. (2009) using Microwave Limb Sounder (MLS) observations recorded during the SPEs of January 2005. They show an HOCl stratospheric enhancement accompanied by a similar decrease in $\mathrm{HCl}$ that clearly demonstrates SPE-induced chlorine activation. 
The conversion of mesospheric $\mathrm{HCl}$ into active chlorine was extensively examined by Winkler et al. (2009) using HALOE data recorded between $62^{\circ}$ and $69^{\circ} \mathrm{N}$ during the SPE of July 2000. In this prior study, the temporal evolution of SPE-induced changes was partially reported since the employed dataset included only three days after the event. Their simulations showed that the magnitude of the $\mathrm{HCl}$ loss cannot be explained solely by the gas phase Reaction (R2) and model runs with parameterized production of $\mathrm{NO}_{\mathrm{x}}$ and $\mathrm{HO}_{\mathrm{x}}$ underestimate the $\mathrm{HCl}$ loss. Indeed several negative ions react with $\mathrm{HCl}$ and form negative chlorine species (e.g., $\mathrm{Cl}^{-}$) mainly in the mesosphere. Then, they can react with $\mathrm{H}$ to reform $\mathrm{HCl}$, or with positive ions releasing, e.g., $\mathrm{Cl}, \mathrm{ClO}$. The increasing ion production rates during a SPE can change the concentration of charged chlorine species and it results in a final net $\mathrm{HCl}$ depletion (additional to the depletion induced by $\mathrm{OH}$ ) and an increase of other neutral chlorine species (e.g. $\mathrm{Cl}, \mathrm{ClO}$ ) (see Winkler et al., 2009). Adding to the model reactions of $\mathrm{HCl}$ with negative ions improves the agreement between simulation results and observed data in the mesosphere (above about $55 \mathrm{~km}$ ). However, a consistent modeldata discrepancy in the stratosphere (where the impact of the negative chlorine chemistry is very small) remains (see also Winkler et al., 2011).

The present paper deals with chlorine changes occurring in the Northern Hemisphere $(\mathrm{NH})$ polar region during January $2005 \mathrm{SPEs}$. Changes in the concentrations of $\mathrm{O}_{3}, \mathrm{HO}_{\mathrm{x}}$, $\mathrm{NO}_{\mathrm{x}}, \mathrm{HNO}_{3}$ and in temperature caused by the SPEs of 17 and 20 January 2005 have been reported in recent studies (e.g., Seppälä et al., 2006; Verronen et al., 2006, 2007, 2011a; Klekociuk et al., 2007; Damiani et al., 2008; Seppälä et al., 2008; Orsolini et al., 2009; Becker and von Savigny, 2010; Jackman et al., 2011). In this paper we study the changes that occurred in a larger set of chlorine species (i.e., $\mathrm{HCl}, \mathrm{ClO}$, $\mathrm{HOCl}$ and $\mathrm{ClONO}_{2}$ ) by using MLS and MIPAS data and Whole Atmosphere Community Climate Model (WACCM) version 4 simulations. In our approach we did not consider ion chemistry (as in Winkler et al., 2009), so we indirectly tested its importance in the lower mesosphere. On the other hand, we studied the temporal evolution of chlorine changes by a larger dataset from polar orbit satellites, that provides a more representative picture of the polar cap region with respect to the prior work (i.e., Winkler et al., 2009).

Recent modelling results (Jackman et al., 2008), compared with MIPAS data recorded during the Halloween storm, revealed good agreement with $\mathrm{HOCl}$ data but poor results for ClO. These difficulties in reproducing SPE-induced $\mathrm{ClO}$ changes have been confirmed in Funke et al. (2011). Moreover, model-data discrepancies are also evident when reproducing SPE-induced changes in $\mathrm{ClONO}_{2}$ (Jackman et al., 2008; Funke et al., 2011). A limitation in these prior studies (i.e., Jackman et al., 2008; Funke et al., 2011) has been the lack of measurements of the most important chlorine reservoir (i.e., $\mathrm{HCl}$ ). On the other hand, when $\mathrm{HCl}$ has been inves- tigated (Winkler et al., 2009), satellite observations of other components were missing.

Some difficulties in studying and reproducing the effects of the SPEs of October-November 2003 (i.e., von Clarmann et al., 2005; Jackman et al., 2008; Funke et al., 2011) were likely due to the early winter vortex being partially illuminated. Since this paper deals with chlorine changes occurring in the NH during January, when the vortex is well established and coincident with the terminator, better modelling results are expected.

Some evidence has been provided (Funke et al., 2011) that the model-data discrepancy in $\mathrm{ClO}$ could arise also from the underestimation of its "background" (i.e., $\mathrm{ClO}$ VMRs before the event) in the upper stratosphere of higher latitudes. The quite good agreement between modelled and observed $\mathrm{ClO}$ before the SPEs of January 2005 is expected to improve modelling results of SPE-induced $\mathrm{ClO}$ changes. Because $\mathrm{ClONO}_{2}$ is strictly dependent on $\mathrm{ClO}$, it should be true also for $\mathrm{ClONO}_{2}$.

In general, the main objectives of this study are (A) to test the ability of WACCM4 to reproduce chlorine changes induced by January 2005 SPEs; and (B) to validate chemical schemes used in current atmospheric models. Other related goals are (1) to investigate the temporal evolution of $\mathrm{HCl}$ changes without the inclusion of the ion chemistry in the model; (2) to check if the favorable conditions of the vortex, roughly coincident with the terminator, allows a better simulation of the changes in $\mathrm{ClO}$ and $\mathrm{ClONO}_{2}$ than in prior studies; and (3) to corroborate the hypothesis of chlorine activation under SPEs.

This paper is divided into eight sections, including the introduction. In Sect. 2 we describe the MLS-Aura and MIPAS-ENVISAT satellite data used. Section 3 reports an overview of the changes in chlorine species induced by the SPEs of January 2005 and compares them with the year-toyear variability and with the variations caused by the SPEs of December 2006. In Sect. 4 we describe the main characteristics of the version 4 of WACCM adapted to reproduce the impact of SPEs on the chlorine species. The space weather and the meteorological conditions of January 2005 are discussed in Sect. 5. In Sect. 6 the spatial distributions and temporal development of measured trace gas concentrations are compared to model calculations and in Sect. 7 these results are discussed in the context of previous work. In Sect. 8 we conclude which features in the data are well understood, which need further investigation, and how further studies could improve our current knowledge on SPE induced chlorine chemistry.

\section{Satellite data}

The main features of the satellite instruments and respective datasets used in the present study will be discussed in this section. 


\subsection{MLS}

The NASA EOS (Earth Observing System) MLS (Waters et al., 2006) is one of the four instruments on Aura satellite, launched on 15 July 2004 to a sun-synchronous near polar orbit with a 13:45 LT (local time) ascending equatorcrossing time. MLS scans the limb of the Earth in the flight forward direction, leading to data coverage from $82^{\circ} \mathrm{S}$ to $82^{\circ} \mathrm{N}$ latitude on every orbit, and measures microwave emission in different spectral regions. Vertical profiles are measured every $165 \mathrm{~km}$ along the suborbital track. Their horizontal resolution is $200-300 \mathrm{~km}$ along-track and $3-9 \mathrm{~km}$ across-track. The vertical resolution depends on the species. It is typically $3-4 \mathrm{~km}$ in troposphere and stratosphere and it degrades up to $8 \mathrm{~km}$ in the mesosphere. MLS records profiles of gas phase chemical abundances, temperature, and cloud ice density. Here we will focus mainly on MLS Version 3.3 ClO, $\mathrm{HCl}, \mathrm{HOCl}, \mathrm{N}_{2} \mathrm{O}$ and temperature Level 2 Data (available at: http://mirador.gsfc.nasa.gov/index.shtml). Detailed validation results for the Version 2.2 MLS measurements are shown in Livesey et al. (2007). Additional information on the differences between Version 2.2 and 3.3 data is reported in Livesey et al. (2011) and in the individual validation papers referenced therein.

MLS ClO data (Santee et al., 2008) have a precision on individual profiles between $0.1-0.3 \mathrm{ppbv}$ and fairly small (lower than $15 \%$ ) systematic uncertainties (or good accuracy) in the middle/upper stratosphere. Vertical resolution, determined from the full width at half maximum (FWHM) of the averaging kernel, is about $3-4.5 \mathrm{~km}$. The useful range for a single profile should be between 100 and $1 \mathrm{hPa}$. MLS $\mathrm{HCl}$ data (Froidevaux et al., 2008) have a precision of 0.2$0.7 \mathrm{ppbv}$ in the stratosphere and lower mesosphere and good accuracy $(10 \%)$. The vertical resolution is about $3 \mathrm{~km}$ in the stratosphere and $4-5 \mathrm{~km}$ in the lower mesosphere. The useful range is between 100 and $0.32 \mathrm{hPa}$. MLS $\mathrm{HOCl}$ data (see Livesey et al., 2011) are quite noisy, with single-profile precision of $0.3-0.4 \mathrm{ppbv}$, and generally require some averaging (e.g., weekly zonal mean) to obtain useful precision. In general, MLS HOCl volume mixing ratios (VMRs) seem to be consistent with MIPAS $\mathrm{HOCl}$ in the 10 to $2 \mathrm{hPa}$ recommended MLS vertical range. The vertical resolution is about $6 \mathrm{~km}$. Mixing ratio values where the a priori information has a strong influence are flagged with negative precision for MLS data, and they should not be used in scientific analyses. Although the recommended upper limit for $\mathrm{HOCl}$ profiles is $2 \mathrm{hPa}, \mathrm{HOCl}$ data used in this study are flagged positively up to $1 \mathrm{hPa}$ (comprised); therefore in this region there is not a strong influence of the a priori. Moreover, during the space weather storm of January 2005, HOCl VMRs increase by a factor of 3 in the upper stratosphere with respect to typical pre-SPE conditions. In this way the increased signal-to-noise ratio allows us to get information up to $1 \mathrm{hPa}$. The singleprofile precision of MLS $\mathrm{N}_{2} \mathrm{O}$ data (Lambert et al., 2007) is about $13-25$ ppbv (7-38\%) and the accuracy is about 3-
$70 \mathrm{ppbv}(9-25 \%)$ for the pressure range 100-4.6 hPa. The vertical resolution determined from FWHM of the averaging kernel is $4-6 \mathrm{~km}$. The scientifically useful range of the $\mathrm{N}_{2} \mathrm{O}$ data is between 100 to $0.46 \mathrm{hPa}$.

Since the magnitude of SPE-induced variability is expected to be of the order of (or less than) the individual profile precision, we will focus on averaged daily data.

\subsection{MIPAS}

MIPAS is a mid-infrared Fourier transform limb emission spectrometer designed and operated for measurement of atmospheric trace species from space (Fischer et al., 2008). It is part of the instrumentation of the European Environmental Satellite (ENVISAT) which was launched into its sun-synchronous polar orbit of $98.55^{\circ} \mathrm{N}$ inclination at about $800 \mathrm{~km}$ altitude on 1 March 2002. MIPAS passes the equator in a southerly direction at 10:00 a.m. LT 14 to 15 times a day, observing the atmosphere during day and night with global coverage from pole to pole. The instrument's field of view is $30 \mathrm{~km}$ in the horizontal direction and approximately $3 \mathrm{~km}$ in the vertical direction. MIPAS operated during January 2005 at a reduced spectral resolution of $0.0625 \mathrm{~cm}^{-1}$ (unapodized) in terms of full width at half maximum. During this period, MIPAS measurements were performed on 10-13 January (middle atmosphere observation mode), 16-18 January (upper troposphere-lower stratosphere (UTLS) observation mode) and 27-28 January (nominal observation mode). Upper atmospheric observation with a scan range of $40-170 \mathrm{~km}$ in terms of tangent heights, taken on 21-24 and 29-30 January, are not considered in this study since they provide only marginal information on $\mathrm{ClONO}_{2}$, the MIPAS key constituent of this study. The middle atmospheric $\mathrm{ClONO}_{2}$ observations taken on 10-13 January (i.e., a week before the SPE event) turned out to be of limited use in providing unperturbed background $\mathrm{ClONO}_{2}$ distributions for this study because of the high temporal variability of this constituent in the vertical range of interest. In the UTLS observation mode, MIPAS records a rear-viewing limb sequence of 19 spectra, corresponding to an along track sampling of approximately $290 \mathrm{~km}$ whereas, in the nominal observation mode, it records 27 spectra, corresponding to a sampling of about $410 \mathrm{~km}$. Tangent heights covered the altitude range from 50 down to $6 \mathrm{~km}$ in the UTLS mode, and 72 to $7 \mathrm{~km}$ in the nominal mode. Trace gas profiles have been retrieved from calibrated geolocated limb emission spectra with the scientific MIPAS level 2 processor developed and operated by the Institute of Meteorology and Climate Research (IMK) in Karlsruhe together with the Instituto de Astrofísica de Andalucía (IAA) in Granada. The general retrieval strategy, which is a constrained multi-parameter non-linear least squares fitting of measured and modeled spectra, is described in detail in von Clarmann et al. (2003).

The $\mathrm{ClONO}_{2}$ data versions used here are V4O_CLONO2_100 (UTLS mode) and V4O_CLONO2_201 

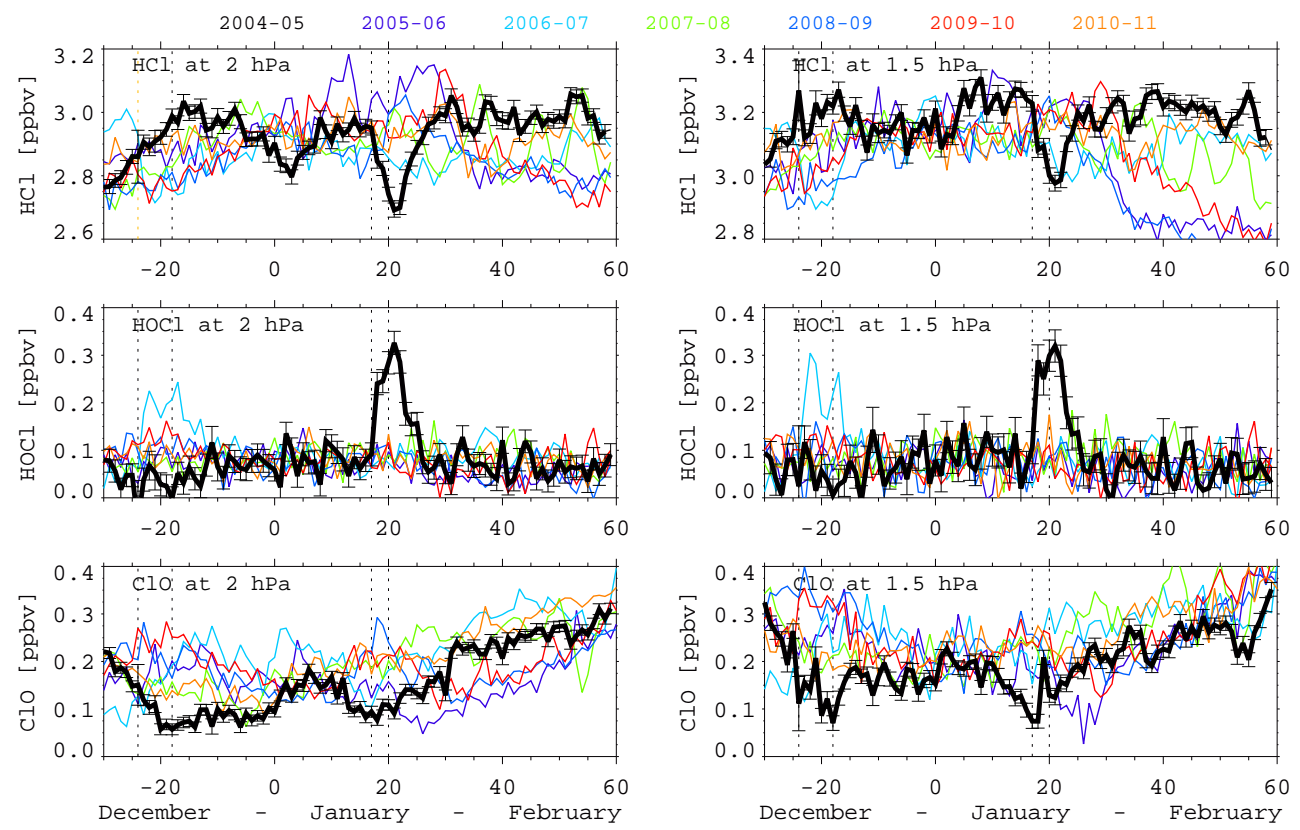

Fig. 1. From top to bottom: time series of daily $\mathrm{MLS} \mathrm{HCl}, \mathrm{HOCl}$ and $\mathrm{ClO}$ at $2 \mathrm{hPa}$ (left column) and $1.5 \mathrm{hPa}$ (right column) averaged over $70-82^{\circ} \mathrm{N}$ from December to February for 2004-2011 years. The vertical dashed lines show the SPEs occurrence. The estimated precision (vertical error bars) for 2004-2005 is reported as a reference.

(nominal mode), all based on the retrieval setup for the original high spectral resolution MIPAS $\mathrm{ClONO}_{2}$ measurements described in Höpfner et al. (2007) (see von Clarmann et al. (2009) for the description of the reduced spectral resolution $\mathrm{ClONO}_{2}$ MIPAS retrievals used in this study). Differences between the two versions are related to the vertical scan range and sampling, implemented in the UTLS and nominal observation modes, and do not affect noticeably the data characteristics in the altitude region of interest (López-Puertas et al., 2005a; Funke et al., 2011). The single measurement precision ranges from 0.06 to $0.12 \mathrm{ppbv}$, increasing with altitude. Vertical resolution is $5-8 \mathrm{~km}$ below $2 \mathrm{hPa}$ and $12-14 \mathrm{~km}$ above. Meaningful data is obtained below approximately $0.5 \mathrm{hPa}(\sim 52 \mathrm{~km})$. Unfortunately no MIPAS $\mathrm{HOCl}$ data are available for the period under investigation, because since 2005 MIPAS measures at reduced spectral resolution not sufficient for retrieval of $\mathrm{HOCl}$.

\section{Changes in chlorine species induced by SPEs and year-to-year variability}

The descending phase of Solar Cycle 23 was characterized by the occurrence of some intense SPEs (e.g., SPEs of January 2005, May 2005, September 2005 and December 2006). In particular, the SPEs of January 2005 and December 2006 occurred under similar seasonal conditions and impacted mainly the atmosphere of the winter hemisphere at Northern Polar regions. In order to evaluate the importance of the chlo- rine changes induced by the SPEs of January 2005 compared with the year-to-year variability and with the effects caused by the SPEs of 7 and 13 December 2006, Fig. 1 shows the time series of (top to bottom) daily $\mathrm{MLS} \mathrm{HCl}, \mathrm{HOCl}$ and $\mathrm{ClO}$ measurements for the winter months (from December through February) of the years 2005-2011 averaged over 70$82^{\circ} \mathrm{N}$ at $2 \mathrm{hPa}$ (left column) and $1.5 \mathrm{hPa}$ (right column) (note that we show two vertical levels fairly close to each other and near the upper limit of the MLS data use because chlorine changes, caused by the SPEs of December 2006 and by yearto-year variability, are visible mainly there). The occurrence of the SPEs of January 2005 and December 2006 is shown by the vertical black dashed lines. The time series of MLS HCl at $2 \mathrm{hPa}$ are illustrated in the upper left panel. Note the strong decrease, likely induced by Reaction (R2) and lasting about 10 days, that occurred after the SPEs of 17 and 20 January 2005. The $\mathrm{HCl}$ decrease is about $0.3 \mathrm{ppbv}$, and the minimum values occurred the day after the SPE of 20 January. They are among the lowest $\mathrm{HCl}$ values ever recorded by MLS at $2 \mathrm{hPa}$ in $\mathrm{NH}$ winter during 2004-2011 years. At lower pressures (up to about $0.1 \mathrm{hPa}$; not shown) these features are similar, with a significant depletion appearing during SPEs and persisting only for a few days. The first proton injection of 17 January seems to cause an initial $\mathrm{HCl}$ decrease, over which an additional depletion caused by the SPE of 20 January is imposed (see Sect. 5.1 for the space weather overview of January 2005 SPEs). The middle left panel of Fig. 1 shows time series of MLS $\mathrm{HOCl}$ measurements as in the upper panel. The sudden SPE-induced enhancement of $\mathrm{HOCl}$ due 
to Reaction (R4) can be easily identified. The $\mathrm{HOCl}$ increase (more than $0.2 \mathrm{ppbv}$ ) in January 2005 is similar in magnitude to the $\mathrm{HCl}$ decrease and suggests SPE-induced chlorine activation. These changes are about 3 times higher than the variability encountered in the other years. Due to the different proton energy spectra of the SPEs of December 2006 compared with the January 2005 ones, in 2006 the strongest effect of the SPE-induced variations is mainly located in the upper stratosphere/mesosphere (roughly above $2-3 \mathrm{hPa}$ ). In contrast, as we will see in the Sect. 6, stratospheric chlorine changes induced by SPEs of January 2005 are evident at least down to 4-5 hPa. Indeed high $\mathrm{HOCl}$ VMRs at $2 \mathrm{hPa}$ are also evident during the SPEs of December 2006 (cyan line). At this pressure surface, the corresponding $\mathrm{HCl}$ decrease depicted in the upper panel, even though partly hidden by the year-to-year variability, is comparable to SPEinduced changes in January 2005. Similar or even more evident changes of $\mathrm{HCl}$ and $\mathrm{HOCl}$ for December 2006 and January 2005 are visible at $1.5 \mathrm{hPa}$ in the upper and middle right panels. These important changes, highlighted also in December 2006, are additional evidence of the presence of chlorine activation under SPE occurrence.

The SPE-induced changes of $\mathrm{HCl}$ were more than $0.2 \mathrm{ppbv}$ at $1.5 \mathrm{hPa}$, but even larger $\mathrm{HCl}$ decrease took place in February 2006, 2009 and 2010 corresponding to periods with strong winter polar vortices in the upper stratosphere following intense stratospheric sudden warming (SSW) events that occurred in January of those years (e.g., Siskind et al., 2007; Manney et al., 2009; Damiani et al., 2010b). Further HCl changes (enhancements) occurred during some SSW events (see for example the $\mathrm{HCl}$ peak at $2 \mathrm{hPa}$ in late February 2008 in the upper-left panel of Fig. 1). Figure 1 shows that $\mathrm{HCl}$ depletions were coupled with intense $\mathrm{HOCl}$ enhancements only during SPEs whereas negligible $\mathrm{HOCl}$ variations occurred after or during SSWs when the active chlorine was mainly in the form of $\mathrm{ClO}$. On the other hand, no clear evidence of ClO changes connected to the SPEs of January 2005 and December 2006 is present at $2 \mathrm{hPa}$. Limited $\mathrm{ClO}$ decreases are present at $1.5 \mathrm{hPa}$ even if they cannot be attributable with certainty to SPE occurrence. In addition, a sudden spike of $\mathrm{ClO}$ VMR (about $0.1 \mathrm{ppbv}$ ) is visible at $1.5 \mathrm{hPa}$ on 19 January 2005. We will examine these issues in Sect. 6.

\section{Description of the whole atmosphere community climate model (WACCM4)}

In the following, MLS and MIPAS data are compared with version 4 of the National Center for Atmospheric Research (NCAR) Whole Atmosphere Community Climate Model (WACCM4) results (http://www.cesm.ucar.edu/ working_groups/WACCM/). An earlier version of the model, WACCM3, was used extensively to investigate the atmospheric effects of SPEs (Jackman et al., 2008, 2009, 2011). The present model version, WACCM4, was used in the re-

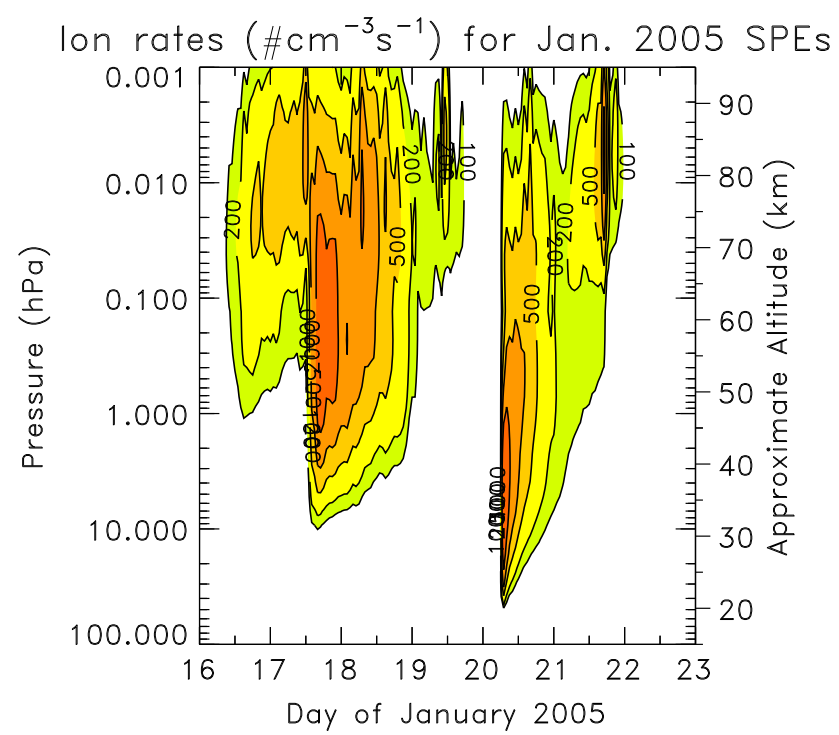

Fig. 2. Hourly average ion pair production rates $\left(\mathrm{cm}^{-3} \mathrm{~s}^{-1}\right)$ as a function of time for 16-22 January 2005. The contour levels are $100,200,500,1000$, and $2000 \mathrm{~cm}^{-3} \mathrm{~s}^{-1}$. Proton flux data from GOES-11 were used to compute ion pair production profiles.

cent Funke et al. (2011) study of the 2003 Halloween SPEs. For this investigation, WACCM4 is forced with meteorological fields from the Modern Era Retrospective-analysis for Research and Applications (MERRA, http://gmao.gsfc.nasa. gov/research/merra/). The same approach was used in the study of the 2003 Halloween SPE (Funke et al., 2011) and the study of the 2006 stratospheric sudden warming (Marsh, 2011). As in those studies, the forcing is achieved by relaxing horizontal winds and temperatures with a time constant of approximately $50 \mathrm{~h}$ from the surface to $40 \mathrm{~km}$. Above that level the forcing is reduced linearly, so that the model is freerunning between $50 \mathrm{~km}$ and the model top. The model has 88 levels in the vertical, with a resolution in the horizontal of 2.5 longitude by 1.9 latitude.

Two sets of simulations were conducted: one with hourly energetic proton ionization rates derived from GOES 11 flux data, and a reference run without ionization. Ionization rates are shown in Fig. 2 and discussed in Sect. 5.1. Neither simulation included highly energetic electron precipitation. This is because this study focuses mainly on the middle/upper stratosphere where, generally, the electrons-induced ionization is somewhat low. Only for $\mathrm{HCl}$ we have reported data up to $0.5 \mathrm{hPa}$. However, as shown below (see Figs. 4, 5 and 6), WACCM4 does a good job in reproducing MLS $\mathrm{HCl}$ at the upper investigated altitudes, excluding (or at least reducing) the possibility of an underestimation of the ionization induced by the significant electrons impact on this altitudinal range. In a future work we will implement the ionization induced by energetic electrons. WACCM4 output closest to each of the satellite (MLS and MIPAS) geo-locations in space and time has been used. It should be noted that in order 
to obtain more realistic comparisons, MLS or MIPAS averaging kernels (AK) have been applied to WACCM4 output. We did not show the impact of the MLS AK applied to the WACCM output because their effect is small. On the other hand the effect of the AK is more evident for MIPAS data and we have shown this in the right panel of Fig. 7.

\section{Space weather and meteorological conditions during January 2005}

Some features of the space weather and the meteorological conditions of the upper stratosphere/lower mesosphere at Norther high latitudes during January 2005 are discussed in the present section.

\subsection{Space weather}

January 2005 was characterised by low/moderate solar activity between 1 and 13 January and after 23 January, while during 15-20 January, the active region 10720 produced five powerful solar flares classified as X1.2, X2.6, X3.8, X1.3 and even X7.1 (see for example The Preliminary Report and Forecast of Solar Geophysical Data, called "The Weekly", available at http://www.swpc.noaa.gov/weekly/index.html). Three SPEs occurred on 16, 17 and 20 January. In the following, we will refer exclusively to the SPEs of 17 and 20 January. The 17 January event was characterised by a large injection of solar particles peaking at 5040 pfu (Particle Flux Units; $1 \mathrm{pfu}=1 \mathrm{p} \mathrm{cm}^{-2} \mathrm{sr}^{-1} \mathrm{~s}^{-1}$ ) at the $10 \mathrm{MeV}$ channel of the National Oceanic and Atmospheric Administration (NOAA) Geostationary Operational Environmental Satellite (GOES) while the $10 \mathrm{MeV}$ peak of the 20 January event was 1860 pfu. Nevertheless, 20 January exhibited the hardest and most energetic particle event of the solar activity cycle 23 (see for instance Damiani et al., 2008). Indeed, on 20 January the peak for the $100 \mathrm{MeV}$ channel of GOES was $652 \mathrm{pfu}$ (we recall that during the Halloween Storm the peak flux at the $100 \mathrm{MeV}$ channel was $155 \mathrm{pfu}$; a list of SPEs affecting the Earth's environment is provided by NOAA at http://www.swpc.noaa.gov/ftpdir/indices/SPE.txt).

The different energy spectra of the two events lead to impacts at quite different layers of the polar atmosphere. In particular, the SPE of 20 January is expected to influence the atmosphere to a deeper level than the 17 January event due to its larger flux of protons at high energy.

It is important to state that the ion production rate was mostly smaller in both 17 and 20 January 2005 compared with the SPEs of October 2003 and July 2000. For example, in the mesosphere, roughly between 1 and $0.01 \mathrm{hPa}$ (about $50-80 \mathrm{~km}$ ), the daily average peak of ion pair production rates was more than $5000 \mathrm{~cm}^{-3} \mathrm{~s}^{-1}$ on 29 October 2003 and on 15 July 2000 , whereas it was about $1000 \mathrm{~cm}^{-3} \mathrm{~s}^{-1}$ on 17 January 2005 (Jackman et al., 2008, 2011). The largest ion production rate in 2005 was located at higher altitudes com- pared with 2003. That influenced the mesospheric $\mathrm{NO}_{\mathrm{x}}$ production by moving the SPE-induced peak of $\mathrm{NO}_{\mathrm{x}}$ in January 2005 toward higher altitudes compared with 2003. Moreover, since the SPE of 20 January was characterised by a very short proton injection, it is important to take into account a temporal resolution of the ion production rate finer than that used in some prior studies (e.g., Jackman et al., 2008, 2011). Therefore, Fig. 2 shows the hourly average ionization rate, from $100 \mathrm{hPa}$ to $0.001 \mathrm{hPa}$, as a function of time for 16-22 January 2005 . The proton flux data from GOES-11 were used to compute ion pair production profiles used in the model (see Jackman et al., 1980, for the methodology). We can note some structure that is not resolvable when looking at the daily average ionization rate (compare this figure with Fig. 1 of Jackman et al., 2011). The most intense ionization, with peak greater than $2000 \mathrm{~cm}^{-3} \mathrm{~s}^{-1}$, is above $1 \mathrm{hPa}$ on $17 \mathrm{Jan}-$ uary whereas it is below $1 \mathrm{hPa}$ on 20 January. However high ionization rates last only a few hours on 20 January.

\subsection{Meteorological conditions}

The absence of strong temperature increases and associated reversals of the zonal winds indicates that the $\mathrm{NH}$ winter of 2004/05 was without major sudden stratospheric warmings (e.g., Chshyolkova et al., 2007; Xu et al., 2009; Damiani et al., 2010b). However, the winter of 2004/05 was particularly cold and dynamically active, especially in the lower stratosphere (Manney et al., 2006; WMO, 2007; El Amraoui et al., 2008). The temperatures exhibit rapid fluctuations in some periods, for example at the beginning and at the end of January. While the polar vortex reached its strongest state and was centred on the pole in December, it was elongated, slightly shifted off the pole and had a decreased extension in the lower stratosphere during these disturbed periods of January (Chshyolkova et al., 2007). Because one of these periods occurred a few days after the SPEs occurrence, this anomalous dynamical vortex behavior likely weakened the chemical impact of the SPEs.

Since meridional transport and mixing can play a key role in the magnitude and spatial distribution of SPE-induced variations, Fig. 3 reports the zonal mean geographic distribution of $\mathrm{N}_{2} \mathrm{O}$ in four periods (from top to bottom: 12 16 January, 17-21 January, 22-26 January and 27-30 January) during the second half of January 2005 as recorded by MLS (left panels) and simulated by WACCM4 (right panels). Due to the strong variation of $\mathrm{N}_{2} \mathrm{O}$ with altitude, we show the $\mathrm{N}_{2} \mathrm{O}$ relative anomaly, with respect to the meridional average $\left(40-82^{\circ} \mathrm{N}\right)$, expressed in percent. Lower abundances of $\mathrm{N}_{2} \mathrm{O}$, surrounded by a pronounced latitudinal gradient, indicate the position of the polar vortex. During the period of the SPEs (17-21 January) MLS shows that the vortex is well defined in the stratosphere up to $2-3 \mathrm{hPa}$, whereas above this layer, a smaller latitudinal gradient is indicative of more intense latitudinal redistribution. This is roughly in agreement with the analysis of the $\mathrm{NH}$ polar 

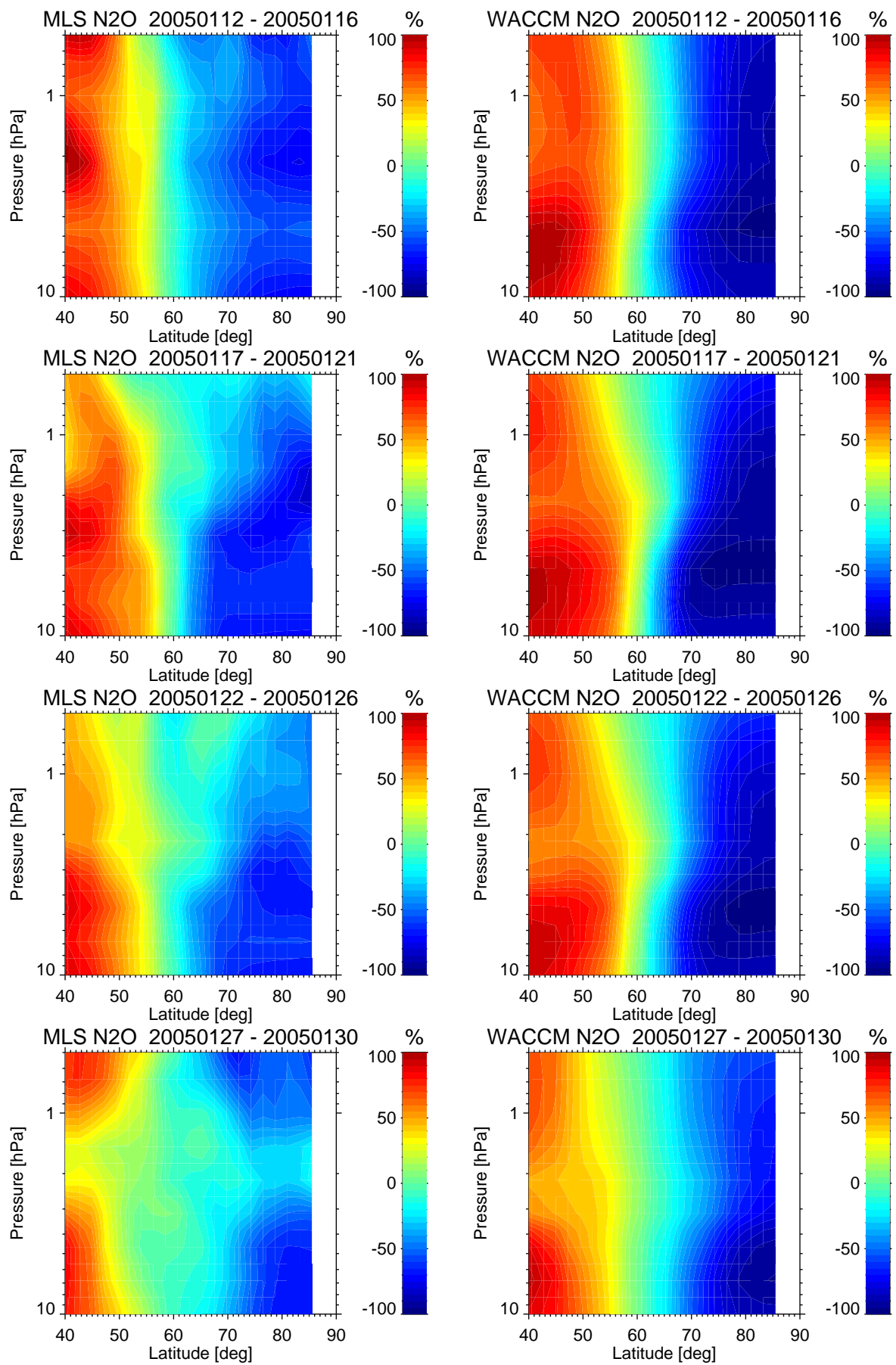

Fig. 3. Zonal mean relative anomaly of $\mathrm{N}_{2} \mathrm{O}$, with respect to the average $\left(40-82^{\circ} \mathrm{N}\right)$, expressed in percent. From top to bottom: zonal mean anomaly of $\mathrm{N}_{2} \mathrm{O}$ before (12-16 January), during (17-21 January) and after (22-26 January and 27-30 January) the SPEs of 17 and 20 January 2005. Left panels: MLS data. Right panels: WACCM4 result.

vortex dynamics of Verronen et al. (2011a) showing increasing horizontal transport and mixing over the altitude range from the lower $(\sim 1 \mathrm{hPa})$ to middle mesosphere during the January 2005 SPEs (however note that the small latitudinal gradient of $\mathrm{N}_{2} \mathrm{O}$ could be indicative also of a well defined but displaced vortex). The area $70-82^{\circ} \mathrm{N}$, to which we will refer in the paper later on (see, for example, Fig. 4), seems to be well inside the vortex (with the consequent weak redistribution) only up to about $3 \mathrm{hPa}$. Above this pressure level, the vortex gets weaker particularly during the following days (lower panels). Therefore SPE-induced effects should be longer lasting in the middle stratosphere 
compared with the effects in the upper stratosphere/lower mesosphere. WACCM4 reproduces the MLS $\mathrm{N}_{2} \mathrm{O}$ pattern quite well but simulates weaker latitudinal redistribution in the mesosphere. The temporal evolutions of daily mean changes of temperature and $\mathrm{N}_{2} \mathrm{O}$ with respect to January average, averaged over $70-82^{\circ} \mathrm{N}$ and $58-70^{\circ} \mathrm{N}$, are reported in the upper panels of Figs. 4 and 5. The patterns of the MLS temperature and $\mathrm{N}_{2} \mathrm{O}$ changes (left panels) are quite similar to each other and show two major variations at the beginning and the end of January connected to the disturbed polar vortex periods. In general higher temperatures and $\mathrm{N}_{2} \mathrm{O}$ values are associated with entrainment of external vortex air into the $70-82^{\circ} \mathrm{N}$ region. Thus they can indicate intrusions or vortex displacement. However, the isolines of the absolute $\mathrm{N}_{2} \mathrm{O}$ abundances (not shown) suggest continuing confined air descent in the middle stratosphere throughout January. Therefore in this region the vortex mixing barrier should remain quite strong at this time according to Chshyolkova et al. (2007). More frequent variations of temperature and $\mathrm{N}_{2} \mathrm{O}$ occur in the upper stratosphere, so, as already discussed, this region of the vortex is less stable compared with lower altitudes. Further, in Fig. 4 we observe an increase of $\mathrm{N}_{2} \mathrm{O}$ values in the upper stratosphere starting around 18 January and becoming more pronounced towards the end of the month. Inspection of the MLS $\mathrm{N}_{2} \mathrm{O}$ data maps (not shown) suggests that, although the polar vortex remains substantially well defined in January, it is elongated and shifted away from the North Pole on many days. In particular, after 27 January, a considerable part of the region inside $70^{\circ} \mathrm{N}$ is occupied by extra-vortex air and obviously that influences the daily means. The WACCM4 simulations follow the changes in MLS temperature and $\mathrm{N}_{2} \mathrm{O}$ quite well, although some discrepancies in their magnitude are visible in the second half of January. Finally, zonal mean changes of temperature and $\mathrm{N}_{2} \mathrm{O}$ on 17-21 January with respect to 12-16 January at 40$90^{\circ} \mathrm{N}$ are reported in the upper panels of Fig. 6. Temperature and $\mathrm{N}_{2} \mathrm{O}$ patterns are consistent with the general behaviour of the vortex already depicted, hence we observe its intensification in the middle stratosphere and its weakening in the upper stratosphere.

\section{Changes in chlorine species: satellite data vs. WACCM4}

To provide the best representation not only for SPEs but also for the meteorological evolution, Fig. 4 shows the temporal evolution of daily mean changes of $\mathrm{HCl}, \mathrm{HOCl}, \mathrm{ClO}$ with respect to January average, averaged over $70-82^{\circ} \mathrm{N}$, therefore under almost complete nighttime conditions (see Sect. 5.2 for the description of temperature and $\mathrm{N}_{2} \mathrm{O}$ panels). The loss in MLS $\mathrm{HCl}$ (left panel) occurred after 17 January and affects nearly all investigated pressures. The strongest decrease (about $0.25 \mathrm{ppbv}$ ) occurs uniformly in a rather wide region ranging from 1.5 to $6 \mathrm{hPa}$ on 21-22 January. This decrease lasts until the end of January slightly descending to around 6-8 hPa. WACCM4 simulations of $\mathrm{HCl}$ (central panel) show a quite good agreement in the lower mesosphere but not in the stratosphere. The $\mathrm{HCl}$ decrease below $2 \mathrm{hPa}$, well evident in MLS data, is not reproduced by WACCM4 results. The right panels of Fig. 4 (WACCM p-b) show the difference between the perturbed (with SPEs) and the base (without SPEs) WACCM4 simulations. Comparing WACCM4 results with WACCM(p-b) shows that, in WACCM4 results, the $\mathrm{HCl}$ decrease caused by the SPEs between 2 and $4-5 \mathrm{hPa}$ is masked by background variability, and the $\mathrm{HCl}$ depletion below $4-5 \mathrm{hPa}$ could be only slightly influenced by the SPE impact. The MLS HOCl temporal evolution shows an increase of more than $0.2 \mathrm{ppbv}$ on 18-21 January 2005. After the first enhancement caused by the SPE of 17 January (more than $0.15 \mathrm{ppbv}$ ), a further $\mathrm{HOCl}$ increase is induced by the SPE of 20 January (see Fig. 4) and HOCl disturbances are slightly moved downward because of the harder spectrum of the second SPE. This enhancement is clearly evident above 4-5 $\mathrm{hPa}$ and lasts up to about 25 January. Both the pattern and the magnitude of these changes are well reproduced by WACCM4.

The lower left panel of Fig. 4 shows the temporal evolution of the MLS ClO. ClO presents a weak increasing trend in the region $3-5 \mathrm{hPa}$, that reaches the highest values after $20 \mathrm{Jan}-$ uary, and a decrease in the upper stratosphere (1-2 hPa) which is strongest around 18 January. These changes seem to be mainly related to dynamical variability. The decrease of $\mathrm{ClO}$ starts before the occurrence of the SPEs and therefore it masks the influence of the solar forcing. However, a further depletion in $\mathrm{ClO}$ occurs on 17 and 18 January. Then, on 19 January a slight $\mathrm{ClO}$ rise is quite evident, followed by another depletion on 20 and 21 January. This behaviour is compatible with a reduction of $\mathrm{ClO}$ via Reaction (R4) and the consequent $\mathrm{HOCl}$ formation. The WACCM4 result (central panels) reproduces the general features of MLS ClO. However, the onset of the particle-induced $\mathrm{ClO}$ depletion is more clearly visible since the observed decreasing trend before the SPEs is less pronounced in the simulation. The rather constant values of the WACCM(p-b) differences (right panel) below $\sim 4 \mathrm{hPa}$ suggest that the observed and modelled $\mathrm{ClO}$ increase is not connected to the SPE.

Figure 5 shows the temporal evolutions as in Fig. 4 but with values averaged over $58-70^{\circ} \mathrm{N}$, and therefore roughly under twilight conditions. In this geographic region MLS $\mathrm{HCl}$ still undergoes a significant decrease (up to about $0.2 \mathrm{ppbv}$ ) that is mostly evident above $1 \mathrm{hPa}$ and around $5 \mathrm{hPa}$. As for the $70-82^{\circ} \mathrm{N}$ region (Fig. 4), WACCM4 does not reproduce the $\mathrm{HCl}$ depletion below about $2 \mathrm{hPa}$. Moreover, unlike the Fig. 4, it clearly underestimates the mesospheric $\mathrm{HCl}$ depletion. From the comparison of WACCM4 results and WACCM(p-b) differences it follows that the simulated $\mathrm{HCl}$ decrease below $4 \mathrm{hPa}$ is likely not due to SPE. 

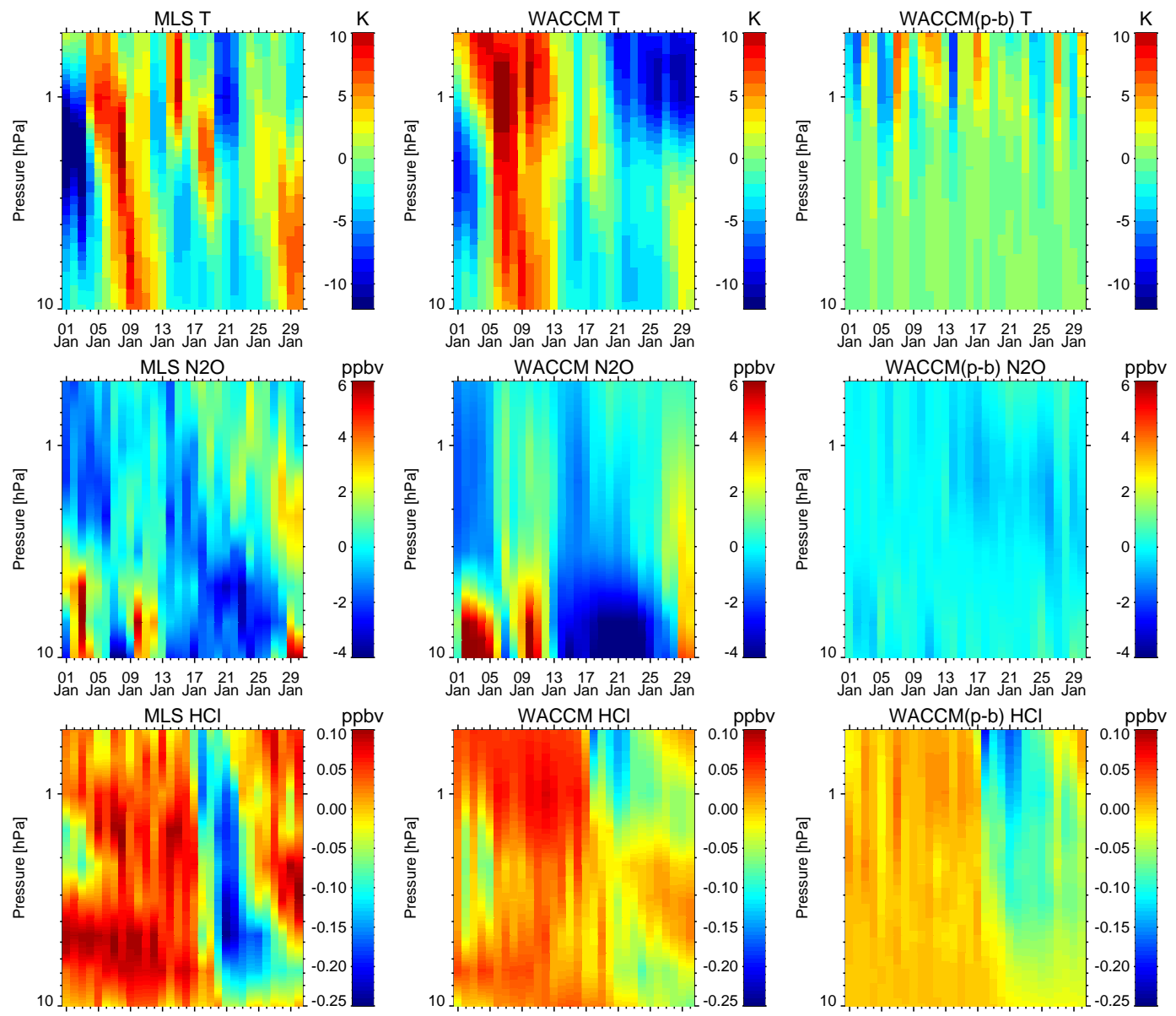

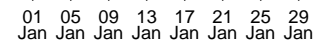

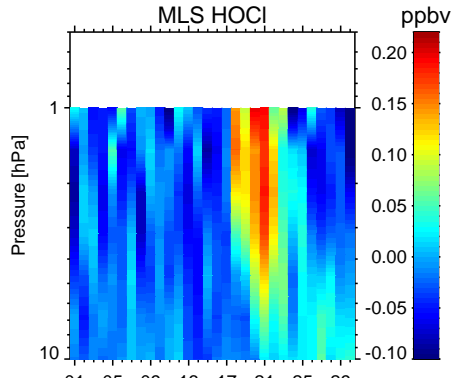

$\begin{array}{llllllll}01 & 05 & 9 & 13 & 17 & 21 & 25 & 29 \\ J & 0.0 & 0\end{array}$

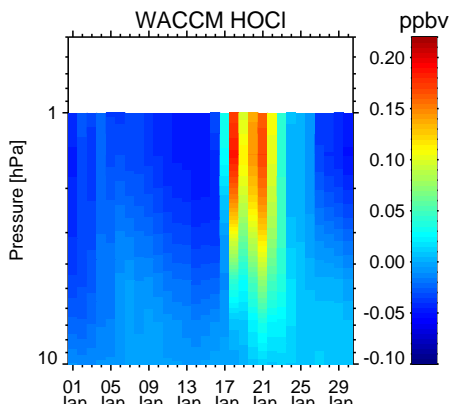

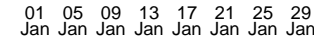

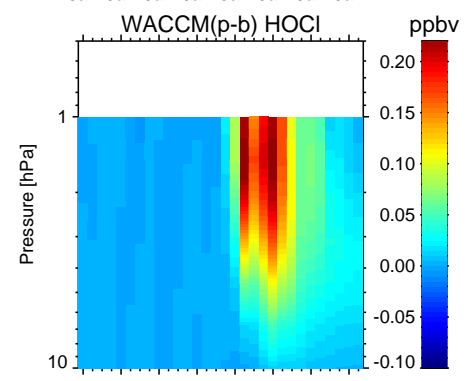

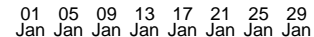
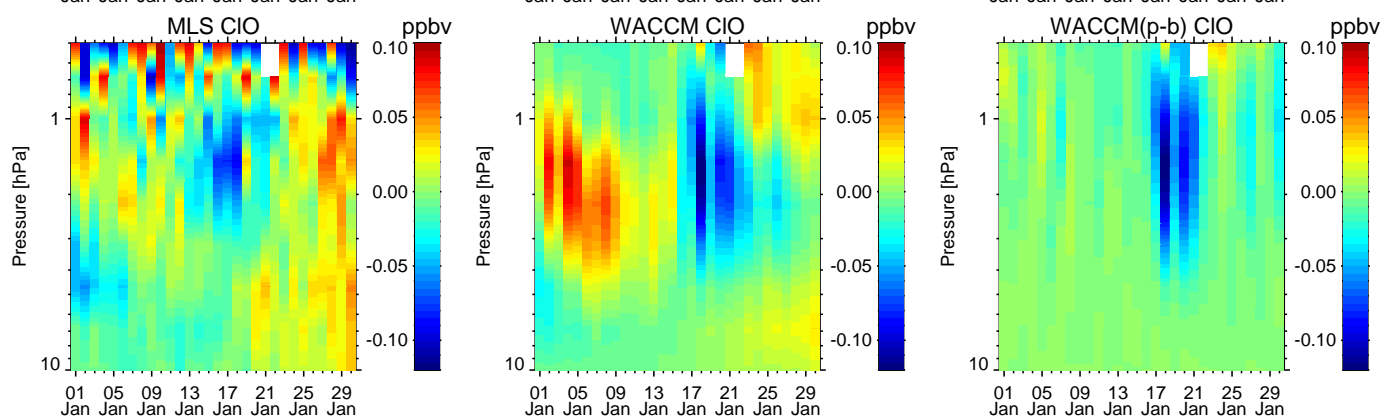

Fig. 4. From top to bottom: temporal development of daily MLS T, $\mathrm{N}_{2} \mathrm{O}, \mathrm{HCl}, \mathrm{HOCl}, \mathrm{ClO}$ during January 2005 , averaged over $70-82^{\circ} \mathrm{N}$, relative to background conditions (January average). Left panels: MLS data. Middle panels: WACCM4 result. Right panels: the model SPE response (perturbed - base). 

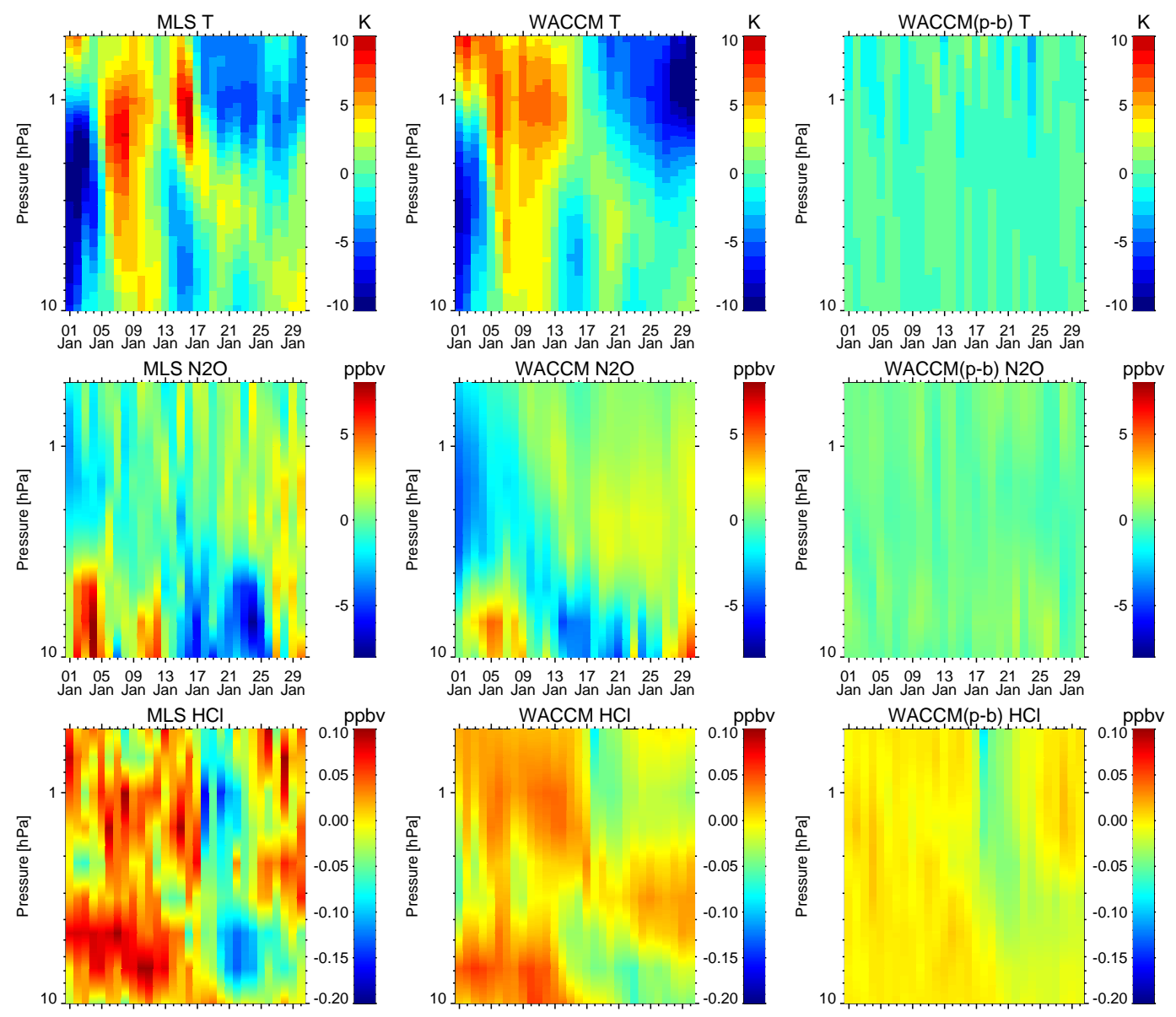

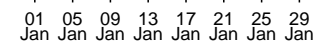
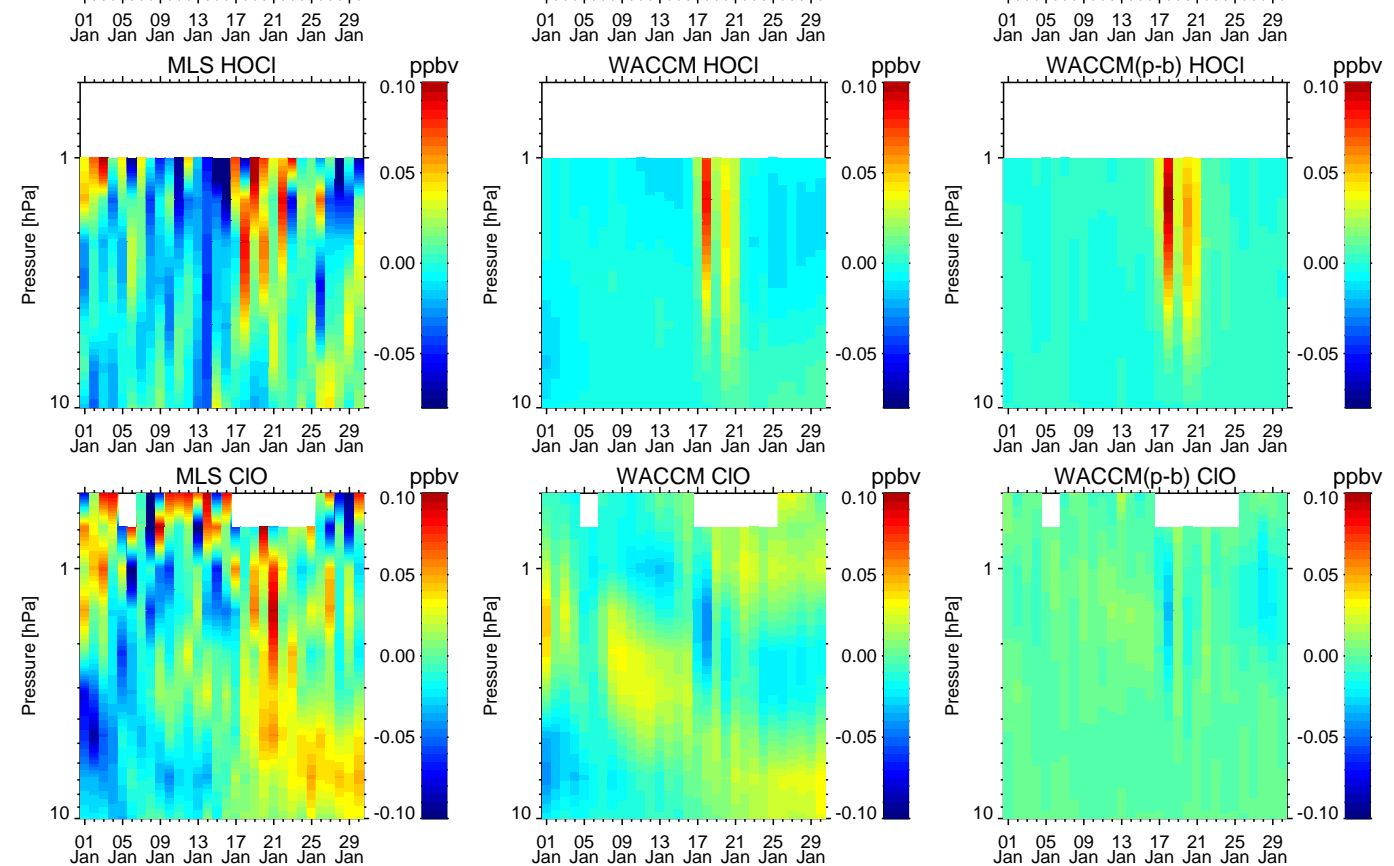

Fig. 5. From top to bottom: temporal development of daily MLS T, $\mathrm{N}_{2} \mathrm{O}, \mathrm{HCl}, \mathrm{HOCl}, \mathrm{ClO}$ during January 2005 , averaged over $58-70^{\circ} \mathrm{N}$, relative to background conditions (January average). Left panels: MLS data. Middle panels: WACCM4 result. Right panels: the model SPE response (perturbed - base). 
It is interesting to examine the short-term variations of $\mathrm{HOCl}$ and $\mathrm{ClO}$ as observed by MLS during the SPEs occurrence. At $58-70^{\circ} \mathrm{N}$, under greater solar illumination with respect to the $70-82^{\circ} \mathrm{N}$ region, an $\mathrm{HOCl}$ enhancement, with peaks of about 0.1 ppbv on 18, 20 and 22 January, is evident around $2-3 \mathrm{hPa}$. $\mathrm{ClO}$ changes are also evident. In general, a $\mathrm{ClO}$ decrease during SPE-influenced days, as seen in Fig. 4, is not present. On the contrary, a blurred $\mathrm{ClO}$ enhancement takes place around $1 \mathrm{hPa}$. Moreover, $\mathrm{ClO}$ increases are quite evident on 19 and 21 January, i.e. not in conjunction with but the day after the $\mathrm{HOCl}$ peaks (note that the $\mathrm{ClO}$ peak of 19 January is evident also at nighttime, see Figs. 1 and 4). This suggests that the SPE-generated $\mathrm{HOCl}$ is photolyzed after the SPEs, leading to $\mathrm{ClO}$ formation via Reaction (R3). In addition, somewhat smaller $\mathrm{ClO}$ increases seem to be present also around 4-6hPa, roughly coincident with the region where stratospheric $\mathrm{HCl}$ decrease occurred. WACCM4 reproduces very well the $\mathrm{HOCl}$ increases whereas it does not show any $\mathrm{ClO}$ enhancement. On the contrary it shows a very small $\mathrm{ClO}$ decrease (as at nighttime), coupled with the SPEs occurrence, that is not present in the MLS data.

Figure 6 illustrates the zonal mean changes of (from top to bottom) $\mathrm{HCl}, \mathrm{HOCl}, \mathrm{ClO}$ on 17-21 January 2005 with respect to 12-16 January 2005 at $40-90^{\circ} \mathrm{N}$ (see Sect. 5.2 for the description of temperature and $\mathrm{N}_{2} \mathrm{O}$ panels). The geographic distribution of MLS $\mathrm{HCl}$ and $\mathrm{HOCl}$ changes (left panels) shows that the perturbations above $2 \mathrm{hPa}$ extend well also into mid-latitudes. This feature is less pronounced in WACCM4 (central panels), most probably related to the underestimation of the latitudinal redistribution at higher altitudes. Also below $4 \mathrm{hPa}$ negative changes of MLS $\mathrm{HCl}$ extend towards lower latitudes, however they are not connected to SPEs occurrence. $\mathrm{N}_{2} \mathrm{O}$ changes at $50-70^{\circ} \mathrm{N}$ (evident in the above panels) are indicative of the different behavior of the polar vortex in these two periods. It was roughly circular in shape and centered over the pole on 17-21 January whereas it was elongated and slightly shifted off the pole on the days before. Therefore, taking into account differences in $\mathrm{HCl}$ abundance between inside and outside of the polar vortex, dynamics is likely the main reason of the negative changes in $\mathrm{HCl}$ at $50-70^{\circ} \mathrm{N}$ visible in both observations and modelling results.

Both $\mathrm{HCl}$ and $\mathrm{HOCl}$ show strongest changes at the highest latitudes, where the photolysis is lowest and the vortex is more isolated. Because of the limited ionization at lower altitudes, only $\mathrm{HCl}$ changes above about $4-5 \mathrm{hPa}$ are likely due to SPEs occurrence (see also the WACCM(p-b) in the right panel of Fig. 6). On the other hand, the evident modeldata $\mathrm{HCl}$ discrepancies below $4-5 \mathrm{hPa}$ inside the vortex could hardly be attributed to unrealistic model dynamics, given the good agreement of observed and modeled tracer (and temperature) evolutions, there. So we cannot exclude that some small SPE-induced $\mathrm{HCl}$ depletion could occur also in this region. However, it could be possible that this inconsistency is caused by a different chemical response to dynamical background variations in the model.

The zonal mean change of $\mathrm{ClO}$ (lower panels of Fig. 6) shows a well defined pattern in both MLS data and WACCM4 results. The observed $\mathrm{ClO}$ depletion of about $0.1 \mathrm{ppbv}$ is present only at high latitudes whereas a $\mathrm{ClO}$ enhancement of a similar magnitude is visible at about 60 $70^{\circ} \mathrm{N}$. WACCM4 results underestimate the response at lower latitudes and overestimate the vertical extent of the $\mathrm{ClO}$ decrease at high latitudes. The different response of $\mathrm{ClO}$ to SPEs as a function of latitude seems to be related to the presence/absence of solar illumination. Therefore, $\mathrm{HOCl}$ is the main active chlorine species during nighttime, whereas both $\mathrm{ClO}$ and $\mathrm{HOCl}$ show perturbations, probably due to SPEs, in twilight regions. However, WACCM(p-b) differences suggest that the $\mathrm{ClO}$ increase at lower latitudes is not linked to SPE occurrence (see also the WACCM(p-b) of Fig. 5). We will reexamine these features in the discussion section.

MIPAS and WACCM4 $\mathrm{ClONO}_{2}$ zonal mean changes with respect to 16-17 January 2005 are shown in Fig. 7 for 18 and 27 January 2005. In the upper panels of Fig. 7 we can see that the zonal mean change on the day after the first SPE does not indicate a SPE-induced $\mathrm{ClONO}_{2}$ response; observed and simulated small changes on the order of $0.03-0.04 \mathrm{ppbv}$ are background variability (see WACCM(p-b) differences). The lower panels show that the zonal mean change on 27 January is characterised by large $\mathrm{ClONO}_{2}$ changes $(\sim 0.2 \mathrm{ppbv})$ around $1 \mathrm{hPa}$ and by a smaller variation $(\sim 0.07 \mathrm{ppbv})$ at about $3 \mathrm{hPa}$. WACCM4 results reproduce well the observations in terms of magnitude and altitude of these peaks. In addition, $\mathrm{WACCM}(\mathrm{p}-\mathrm{b})$ differences suggest that the $\mathrm{ClONO}_{2}$ changes around $3 \mathrm{hPa}$ are mainly attributable to SPE occurrence, whereas the enhancement at $1 \mathrm{hPa}$ is induced by both background variability and SPE occurrence, with the latter contributing $\sim 0.1 \mathrm{ppbv}$ mainly at latitudes higher than $70^{\circ} \mathrm{N}$ and between 1 and $2 \mathrm{hPa}$.

\section{Discussion}

The analysis presented above highlighted the presence of chlorine activation under SPE conditions although some aspects still remain unclear. Therefore, it is worthwhile to discuss these results in the light of past findings. Some important features distinguish the January 2005 SPEs from other events (e.g., SPEs of July 2000 and October-November 2003) investigated in the context of their impact on chlorine. First, the polar night region was much more extended in January 2005 compared with October 2003 and July 2000. The well established vortex coincided with the terminator in 2005 , while in 2003 , the early winter vortex was partially illuminated, and the SPE of July 2000 was investigated only in the summer hemisphere. It is also important to emphasise the smaller ionization rates modeled for January 2005 compared with other events (see Sect. 5.1), which caused a smaller 

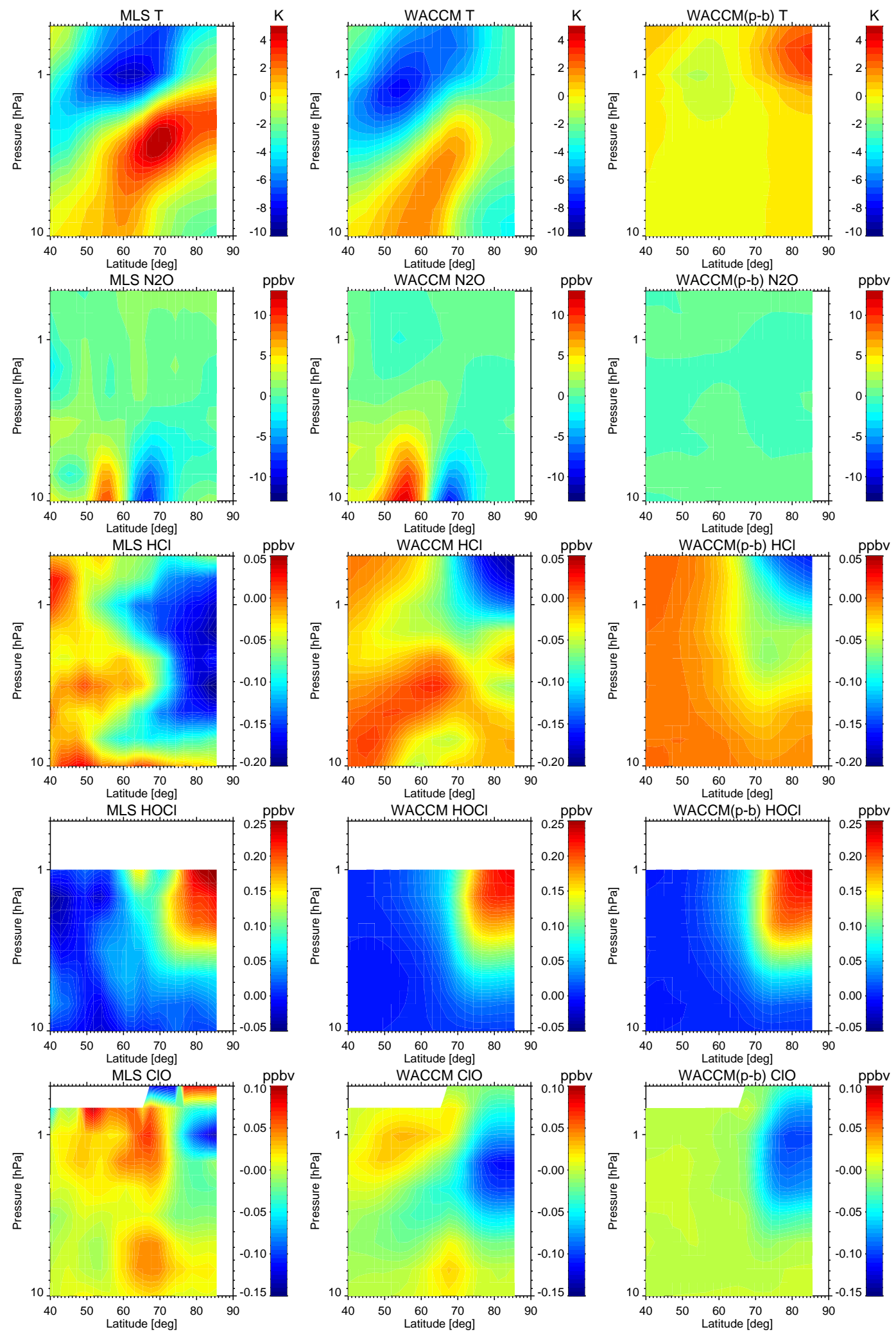

Fig. 6. From top to bottom: zonal mean change (17-21 January 2005 with respect to 12-16 January 2005) of MLS T, $\mathrm{N}_{2} \mathrm{O}, \mathrm{HCl}, \mathrm{HOCl}, \mathrm{ClO}$ at $40-90^{\circ} \mathrm{N}$. Left panels: MLS data. Middle panels: WACCM4 result. Right panels: the model SPE response (perturbed - base). 

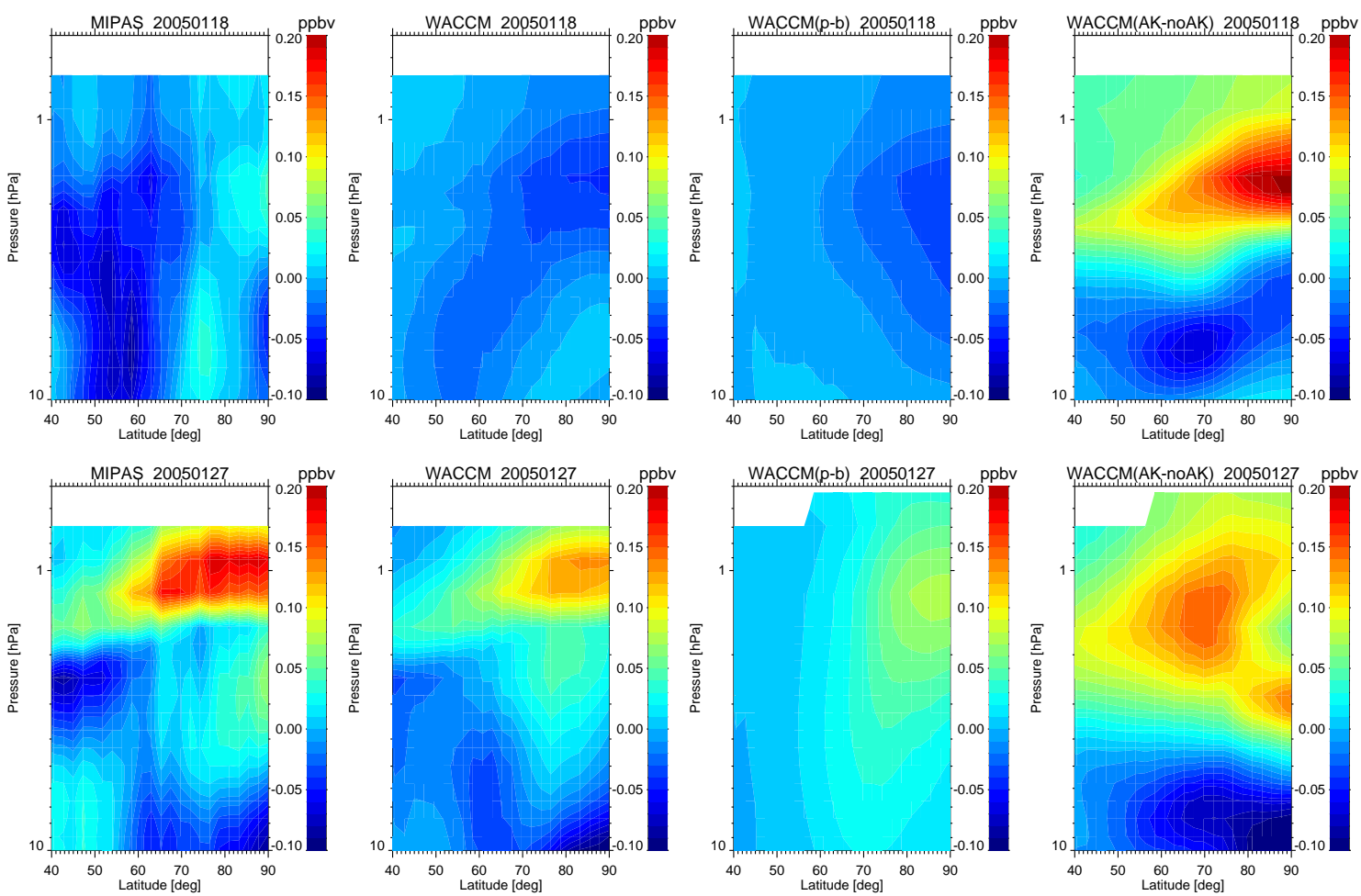

Fig. 7. $\mathrm{ClONO}_{2}$ zonal mean change on 18 (upper panels) and 27 January 2005 (lower panels) with respect to 16-17 January 2005 at 40$90^{\circ}$ N. From left to right: MIPAS data, WACCM4 result with MIPAS averaging kernels applied, the model SPE response (perturbed - base), WACCM4 result with MIPAS averaging kernels applied - the original model result.

production of $\mathrm{NO}_{\mathrm{x}}$ at upper altitudes in 2005 compared to 2003. As we will see in the following, these elements are important in order to explain the impact of the investigated events on the atmospheric composition.

\subsection{HCl changes}

To our knowledge, only Winkler et al. (2009) have carefully examined the variation of $\mathrm{HCl}$ under SPE conditions. However, the different time of the year of the examined SPE and the analysis performed by means of solar occultation data and a 2-D chemistry model (with ion chemistry) prevent a full comparison of their results with ours. Some differences in the vertical distribution of the $\mathrm{HCl}$ depletion, caused by the different SPEs, are evident. HALOE data in 2000 , recorded in the illuminated $\mathrm{NH}$, show variability between $65 \mathrm{~km}(\sim 0.1 \mathrm{hPa})$ and $35 \mathrm{~km}(\sim 5 \mathrm{hPa})$, with the maximum stratospheric $\mathrm{HCl}$ depletion (about $0.4 \mathrm{ppbv}$ ) at $50 \mathrm{~km}$ and a roughly constant reduction of this enhancement down to $35 \mathrm{~km}$, where the $\mathrm{HCl}$ changes are small ( $\sim 0.05 \mathrm{ppbv})$. In contrast, MLS data in January 2005 show the maximum $\mathrm{HCl}$ loss (of less than $0.25 \mathrm{ppbv}$ ) uniformly distributed in a rather wide region ranging from 1.5 to $6 \mathrm{hPa}$. These differences are mainly related to the stratospheric background variations in January 2005 , to the different atmospheric seasonal condi- tions at Northern Polar regions in July and January, and to the occurrence of two successive SPEs in January 2005.

In fact, it is important to identify the distinct contributions arising from different sources to the $\mathrm{HCl}$ decrease in January 2005. In January 2005 we have the overlap of the effects of two SPEs, with the second one, characterized by a harder spectrum, able to impact the already low stratospheric $\mathrm{HCl}$ values persisting longer at nighttime (Fig. 4). On the contrary, only one SPE (even if more intense) occurred in July 2000. The diverse proton energy spectra during the two SPEs in January 2005 is reflected in the shape of the $\mathrm{HCl}$ decrease. The first depletion $(\sim 0.2 \mathrm{ppbv})$, due to 17 January SPE, affected mesospheric altitudes on 18 January. In this case, the location of the maximum $\mathrm{HCl}$ depletion (around $1 \mathrm{hPa}$ ) is roughly in agreement with previous results. Then, a second and more intense stratospheric decrease, superimposed over the previous one, occurred after the 20 January SPE. This strongest decrease occurs rather uniformly in the upper and middle stratosphere on 21-22 January and it lasts until the end of January around 6-8 hPa. However, because of the lack of significant ionization at these altitudes, this long lasting tail of $\mathrm{HCl}$ decrease seems not to be connected to the SPE occurrence. The expected low SPE-induced impact below about $4 \mathrm{hPa}$ is likely superimposed over background variations (see Sect. 6). It results in a stronger than expected $\mathrm{HCl}$ decrease with a maximum around $5 \mathrm{hPa}$ on 21-22 January and in the 
evident $\mathrm{HCl}$ tail persisting until the end of January. Hence, these model-data discrepancies, mainly present at about 5$8 \mathrm{hPa}$ (see Figs. 4 and 5), are mostly due to background atmospheric variability. Their investigation is beyond the scope of this study and they will require a specific analysis.

An additional element that could play a role in explaining these differences in the $\mathrm{HCl}$ decrease is related to the different background of OH VMRs in January and July in Northern Polar regions. The $\mathrm{OH}$ VMRs in the stratosphere and mesosphere depend mainly on the Solar Zenith Angle (SZA). In the upper stratosphere, between $7 \mathrm{hPa}$ and $1 \mathrm{hPa}$, the typical daytime $\mathrm{OH}$ abundance is about $0.1-0.6 \mathrm{ppbv}$, with lower values at lower altitudes, whereas during the night the $\mathrm{OH}$ VMRs are uniformly very close to zero. In order to have appreciable $\mathrm{HCl}$ changes, the SPE-induced $\mathrm{OH}$ increase has to be, at least, of the same order of magnitude (or larger) as the $\mathrm{OH}$ background. Therefore differences in the vertical distribution of the HCl depletion, caused by the SPEs of July 2000 and January 2005, had likely been influenced by differences in the background of OH VMRs.

A further difference between the SPEs of January 2005 and July 2000 is the duration of the mesospheric $\mathrm{HCl}$ decrease. Indeed, $\mathrm{HCl}$ recovered in a couple of days in July 2000, whereas the depletion lasted more than one week in January 2005. Obviously the occurrence of two successive SPEs in January 2005 is the first reason of the correspondent longer $\mathrm{HCl}$ depletion. Moreover, the confinement maintained by the polar vortex in January 2005 and the absence of photolysis at high latitudes, that likely prevented a quick shift towards $\mathrm{HCl}$ from the SPE-induced active forms (e.g., the destruction of $\mathrm{HOCl}$ by photolysis), are additional causes compared to the polar summer conditions in July 2000.

WACCM4 reproduces quite well the $\mathrm{HCl}$ depletion in the lower mesosphere (about $0.2 \mathrm{ppbv}$ ) at nighttime on $18 \mathrm{Jan}$ uary. Also at the upper mesospheric altitudes where the $\mathrm{HCl}$ depletion is even more intense (not shown), WACCM4 results are in fair agreement with experimental data without the necessity of including ion chemistry. However, WACCM4 underestimates the mesospheric $\mathrm{HCl}$ response at $58-70^{\circ} \mathrm{N}$ (see Fig. 5). This could be related to the underestimation of the redistribution of the bulk of depleted $\mathrm{HCl}$ molecules. On the other hand WACCM4 slightly overestimates the $\mathrm{HCl}$ depletion in the nighttime mesosphere at $70-82^{\circ} \mathrm{N}$ (see Fig. 4) on 21 January. Since Verronen et al. (2011a) showed a strong mesospheric horizontal transport on 21 January, these modeldata differences are a further corroboration of the imperfect reproduction of the mesospheric horizontal mixing by WACCM4 during this period.

In the upper stratosphere (roughly above $2-3 \mathrm{hPa}$ ), where $\mathrm{HCl}$ changes are related to the SPEs, the model tends to underestimate the observed depletion (see Figs. 4 and 5). The lack of $\mathrm{HCl}$ loss (or its underestimation) in the WACCM4 results in this region is in line with the difficulties encountered by Winkler et al. (2011) when modeling the stratospheric $\mathrm{HCl}$ response during the July 2000 event. The cause is not easily understandable. Possible reasons that could contribute to explain such difference are:

1. SPE-induced ionization included in the model is too small, either due to an underestimation of proton fluxes or due to the neglection of electron-induced ionization (Verronen et al., 2011b). However, MLS OH is reproduced by WACCM4 quite well down to $3 \mathrm{hPa}$ (not shown), so this possibility appears to be unlikely.

2. The ion chemistry in the model is neglected.

3. The uncertainty of the rate constant of Reaction (R5) included in the model with the JPL rate constant (Sander et al., 2006). It is connected to the deactivation of $\mathrm{ClO}$ into the reservoir $\mathrm{HCl}$ but probably could play only a limited role in this discrepancy.

This model-data discrepancy suggests that deficiencies in chemical schemes involving chlorine species in the upper stratosphere could be present. Further analyses will be necessary in order to explain the model-data discrepancies.

\subsection{ClO and $\mathrm{HOCl}$ changes}

It is also interesting to examine in detail the behaviour of $\mathrm{ClO}$ and HOCl. von Clarmann et al. (2005) showed an increase of MIPAS CIO VMRs immediately after the SPE of September-October 2003. A recent analysis based on reprocessed IMK/IAA MIPAS data (Funke et al., 2011) clarified that MIPAS recorded increased $\mathrm{ClO}$ (about $0.1 \mathrm{ppbv}$ ) mainly outside the polar night region, whereas a $\mathrm{ClO}$ decrease (about $0.2 \mathrm{ppbv}$ ) occurred in the polar night region. This is consistent with the MLS results presented in Fig. 6 where the $\mathrm{ClO}$ decrease is roughly confined to the polar night sector and increased $\mathrm{ClO}$ is evident at the terminator (in particular above $2 \mathrm{hPa}$ at $\left.60-70^{\circ} \mathrm{N}\right)$. However, WACCM4 simulations indicate that only the $\mathrm{ClO}$ decrease is caused by SPEs. On the other hand, the strong $\mathrm{HOCl}$ enhancement is well reproduced by WACCM4 at nighttime conditions.

During the daytime, $\mathrm{HOCl}$ is quickly destroyed by photolysis

$\mathrm{HOCl}+h v(\lambda<503 \mathrm{~nm}) \rightarrow \mathrm{Cl}+\mathrm{OH}$

and by reaction with $\mathrm{OH}$ (or atomic oxygen):

$\mathrm{OH}+\mathrm{HOCl} \rightarrow \mathrm{H}_{2} \mathrm{O}+\mathrm{ClO}$.

Funke et al. (2011) suggested that, because $\mathrm{OH}$ is the dominant $\mathrm{HO}_{\mathrm{x}}$ constituent during daytime (at least in the upper stratosphere; below roughly $5 \mathrm{hPa} \mathrm{HO}_{2}$ starts to be comparable to $\mathrm{OH}$ and gets even larger than $\mathrm{OH}$ at lower altitudes) and Reactions (R6) and (R7) are the major daytime processes, active chlorine is mainly in the form of $\mathrm{ClO}$ under these conditions. The $\mathrm{ClO}$ enhancements in MIPAS data outside the polar region during the Halloween storm could then be related to SPE-induced chlorine activation if the production of $\mathrm{HO}_{\mathrm{x}}$ was above the typical $\mathrm{HO}_{\mathrm{x}}$ background levels. 
In January 2005 MLS data indicate that the SPE-induced OH rise is comparable with background levels (about $0.05 \mathrm{ppbv}$ ) at $1 \mathrm{hPa}$ and $65-70^{\circ} \mathrm{N}$, coinciding with the altitude of the $\mathrm{ClO}$ peak (see left panel of Fig. 6), whereas there are not appreciable changes at lower altitudes.

Figure 6 shows that the region of low $\mathrm{HCl}$ values extends towards low latitudes in the upper $(\sim 1 \mathrm{hPa})$ and middle stratosphere $(\sim 7 \mathrm{hPa})$, whereas it remains more confined inside high latitudes around $3 \mathrm{hPa}$. The MLS ClO structure in the same region (roughly $60-70^{\circ} \mathrm{N}$ ) presents higher $\mathrm{ClO}$ values at the upper altitudes, where there is availability of active chlorine molecules arising from the $\mathrm{HCl}$ depletion via SPE-induced $\mathrm{OH}$, whereas little change was recorded around $3 \mathrm{hPa}$. Further, $\mathrm{HOCl}$ enhancements are present also at 60 $70^{\circ} \mathrm{N}$ above about $3 \mathrm{hPa}$ (Fig. 6). Increased production of $\mathrm{HOCl}$ in the middle stratosphere, induced by accelerated odd hydrogen chemistry (via Reaction R4), has been reported by von Clarmann et al. (2009) in association with a displacement of the polar vortex towards lower latitudes during a SSW event. SPE occurrence represents a further example of accelerated odd hydrogen chemistry as indicated by both $\mathrm{HOCl}$ and $\mathrm{ClO}$ increases between $58-70^{\circ} \mathrm{N}$ (see Fig. 5). Comparing the temporal evolution of $\mathrm{ClO}$ and $\mathrm{HOCl}$ zonal means, it follows that $\mathrm{ClO}$ peaks seem to temporally follow $\mathrm{HOCl}$ changes. This suggests that SPE-induced $\mathrm{HOCl}$ increases may have been photolyzed leading to the shift from $\mathrm{HOCl}$ to $\mathrm{ClO}$. Therefore, clues for a deactivation later after the SPEs of January 2005 seem to be present. However, WACCM(p-b) of Figs. 5 and 6 does not show any SPEinduced $\mathrm{ClO}$ enhancements whereas it reproduces well the $\mathrm{HOCl}$ changes also outside the polar night terminator. The dynamically active polar vortex could also have contributed to complicate the situation by masking and mixing chlorine changes.

Considerable uncertainty persists in laboratory measurements of the rate constant for the Reaction (R4). Some studies (e.g., Kovalenko et al., 2007; von Clarmann et al., 2009) pointed out the necessity of increasing it towards the value from Stimpfle et al. (1979) that is about a factor-of-two faster than the rate constant (Sander et al., 2006) used in WACCM4. Recently, the new JPL recommendation (Sander et al., 2011) was updated towards a higher value. However this remains an open issue and the possibility of increasing the agreement between observed data and model results by uploading the rate constant should be taken into account.

The SPE-induced $\mathrm{HOCl}$ changes recorded by MLS in January 2005 are similar to the $\mathrm{HOCl}$ variations recorded by MIPAS during the Halloween storm (about 0.25 ppbv). Even if we consider only the enhancement induced by the first SPE on 18 January (close to $0.2 \mathrm{ppbv}$ at $1.5 \mathrm{hPa}$ ), therefore ignoring the additional increase due to the second SPE, the depletion still remains comparable. Because of the lower ionization of January 2005 (about 4-5 times less, see Sect. 5.1) this seems difficult to explain. The amount of SPE-induced $\mathrm{HOCl}$ enhancement is linked to the abundance of $\mathrm{HO}_{2}$ that depends on the ionization; however also the seasonal conditions could play an important role. Since, under nighttime conditions, $\mathrm{HO}_{\mathrm{x}}$ is in steady state also during a SPE, its abundance is proportional to ionization. The $\mathrm{HO}_{\mathrm{x}}$ production induced by SPEs occurs mainly in the form of $\mathrm{OH}$ and H (Solomon et al., 1981). Then, OH can react with ozone and $\mathrm{H}$, in presence of a third body, with oxygen molecules, both leading to $\mathrm{HO}_{2}$ formation. As the production of $\mathrm{HO}_{2}$ depends on the density, it follows that the $\mathrm{HO}_{2} / \mathrm{OH}$ ratio increases from the mesosphere down to the stratosphere under $\mathrm{SPE}$ conditions. Moreover, since the background of $\mathrm{OH}$ is higher than $\mathrm{HO}_{2}$ in the daytime upper stratosphere and mesosphere (i.e., the region affected by SPE), compared with its very low abundances at nighttime, this ratio is more elevated at nighttime. On the other hand, $\mathrm{HO}_{\mathrm{x}}$ losses are dominated by reactions between $\mathrm{OH}$ and $\mathrm{HO}_{2}$. In this way, the $\mathrm{HO}_{2} / \mathrm{OH}$ ratio, i.e. $\mathrm{HO}_{\mathrm{x}}$ partitioning, influences the $\mathrm{HOCl}$ formation since it controls the availability of $\mathrm{HO}_{2}$. Therefore, the higher SPE-induced $\mathrm{HO}_{2} / \mathrm{OH}$ ratio in January 2005 , due to the almost complete nighttime conditions, contributes to an $\mathrm{HOCl}$ enhancement similar to that of 2003 despite the lower ionization and total $\mathrm{HO}_{\mathrm{x}}$ production.

The recent studies of Jackman et al. (2011) and Funke et al. (2011) highlighted that models tend to overestimate the SPE-induced production of $\mathrm{HO}_{2}$ and $\mathrm{H}_{2} \mathrm{O}_{2}$ and, hence, the $\mathrm{HO}_{2} / \mathrm{OH}$ ratio under SPE conditions. As discussed, this ratio plays an important role in the partitioning of chlorine species. The MLS $\mathrm{HO}_{\mathrm{x}}$ data could help us to constrain the $\mathrm{HO}_{2} / \mathrm{OH}$ ratio. However the presence of a bias in $\mathrm{MLS} \mathrm{HO}_{2}$ (Pickett et al., 2008), which normally requires taking day-night differences to be removed, prevents an accurate analysis (SPEinduced $\mathrm{HO}_{2}$ variations are evident mainly under nighttime conditions). The biases are typically small compared with SPE effects. Using differences of the nighttime data between two close time periods (to minimize the bias effect) it is possible to highlight SPE-induced $\mathrm{HO}_{2}$ changes (Jackman et al., 2011) although in this way the exact $\mathrm{HO}_{2} / \mathrm{OH}$ ratio can be affected.

\section{$7.3 \quad \mathrm{ClONO}_{2}$ changes}

Also the behaviour of $\mathrm{ClONO}_{2}$ deserves special attention. Figure 7 shows that $\mathrm{ClONO}_{2}$ changes are not present on the day after the first SPE. On 27 January we note an enhancement of $\sim 0.2 \mathrm{ppbv}$ at about $1 \mathrm{hPa}$. The work of Funke et al. (2011), who use a reprocessed version of the $\mathrm{ClONO}_{2}$ data set presented by von Clarmann et al. (2005), shows the SPE-induced $\mathrm{ClONO}_{2}$ peak $(\sim 0.4 \mathrm{ppbv})$ at about $3 \mathrm{hPa}$ in October-November 2003. Either the altitude or the magnitude is somewhat different compared with the peak value observed on 27 January 2005. The $\mathrm{ClONO}_{2}$ formation depends on the availability of $\mathrm{NO}_{2}$ and $\mathrm{ClO}$, and on the density. In January 2005 the SPE-induced production of odd nitrogen was considerably lower compared to the October-November 2003 events. Jackman et al. (2008) estimated that the $\mathrm{NO}_{\mathrm{y}}$ 
production in 2005 was $\sim 4$ times smaller than in 2003, which could lead to a lower production of $\mathrm{ClONO}_{2}$ in January 2005. Moreover, we could expect a $\mathrm{ClONO}_{2}$ enhancement at somewhat lower altitudes compared with the altitudes of the SPEinduced $\mathrm{NO}_{2}$ layer (because of the pressure dependence of $\mathrm{ClONO}_{2}$ formation). Because of the different distribution of the ionization (see Sect. 5.1), the SPE-induced $\mathrm{NO}_{2}$ formation in January 2005 should occur mainly at higher altitudes compared with 2003. Hence, it is likely that the $\mathrm{ClONO}_{2}$ increase ( $\sim 0.2 \mathrm{ppbv}$ ) of 27 January at about $1 \mathrm{hPa}$ (Fig. 6) is due, at least partly, to the SPEs. This seems compatible with the incomplete recovery of $\mathrm{HCl}$ around $1 \mathrm{hPa}$ lasting until the end of January (see Figs. 4 and 5) caused by an initial chlorine activation $(\mathrm{HCl} \rightarrow \mathrm{ClO})$ and a further possible deactivation into the $\mathrm{ClONO}_{2}$ reservoir. The elevated altitude of $\mathrm{HNO}_{3}$ enhancements that occurred during the SPEs of January 2005 and recently reported by Verronen et al. (2011a) (with peak around $60 \mathrm{~km}$, so at altitudes higher than previous observed $\mathrm{HNO}_{3}$ variations caused by SPEs (e.g., LópezPuertas et al., 2005a) is a further element corroborating our finding of SPE-induced $\mathrm{ClONO}_{2}$ changes at elevated altitudes.

It is puzzling that $\mathrm{ClO}$ and $\mathrm{ClONO}_{2}$ are quite well reproduced by WACCM4 in January 2005 but not in OctoberNovember 2003. Funke et al. (2011) argued that in 2003 the background $\mathrm{ClO}$ was underestimated by models, leading to modelled $\mathrm{ClO}$ changes smaller than observed. In contrast, in 2005 WACCM4 reproduces quite well the background $\mathrm{ClO}$ VMRs, and hence also the modelled SPE-induced changes are closer to observed data. A possible explanation could be that the chemical schemes of $\mathrm{ClO}$ formation/loss under twilight conditions are not well represented in the models. Another possible explanation could be that models underestimate the actual isentropic mixing within the vortex. In 2003, a weaker mixing of "illuminated" and "dark" air masses inside the partially illuminated vortex could lead to lower modelled $\mathrm{ClO}$ abundances in the polar regions. In contrast, with a well established vortex coincident with the terminator as in 2005 the modelled results should be closer to the satellite data. The lower $\mathrm{ClO}$ abundance in the models during October 2003 is the main reason for the model underestimation of $\mathrm{ClONO}_{2}$. In contrast, in January 2005 the modelled $\mathrm{ClO}$ VMRs are similar to MLS ClO values, hence also WACCM4 $\mathrm{ClONO}_{2}$ output reproduces the MIPAS data well.

\section{Conclusions}

For the first time the main contributors to the $\mathrm{Cl}_{\mathrm{y}}$ family recorded by two different satellites have been shown and compared with a state-of-the art chemistry climate model under SPE conditions. This has been done taking into account also $\mathrm{HCl}$, the most important chlorine reservoir, to which many uncertainties (confirmed by the present study), linked to its response to SPEs, are related. MLS measurements of chlorine species (i.e., $\mathrm{HCl}, \mathrm{ClO}$ and $\mathrm{HOCl}$ ), $\mathrm{N}_{2} \mathrm{O}$, and temperature together with MIPAS $\mathrm{ClONO}_{2}$ recorded during and after the SPEs of 17 and 20 January 2005 have been analysed and modelled with version 4 of the Whole Atmosphere Community Climate Model (WACCM4). SPE-induced chlorine repartitioning $(\mathrm{HCl} \rightarrow \mathrm{ClO} \rightarrow \mathrm{HOCl}$ and, after the events, $\mathrm{ClONO}_{2}$ ) has been identified. In the observations, $\mathrm{HCl}$ decrease is present at almost all the investigated altitudes (i.e., $10-0.5 \mathrm{hPa}$ ). The strongest decrease (about $0.25 \mathrm{ppbv}$ ) occurs uniformly in a rather wide region ranging from 1.5 to $6 \mathrm{hPa}$ on 21-22 January and it recovers in a week in the upper stratosphere. However below $4 \mathrm{hPa}$, this decrease is unlikely to be related to the SPE. Instead, it seems to be related to background variations.

$\mathrm{ClO}$ abundances did not undergo very large changes. However, a $\mathrm{ClO}$ decrease of up to $0.1 \mathrm{ppbv}$ has been identified in the upper stratosphere at high latitudes, whereas a $\mathrm{ClO}$ increase of similar magnitude has been found close to the terminator. An $\mathrm{HOCl}$ enhancement of more than $0.25 \mathrm{ppbv}$ occurred roughly in the same region where the $\mathrm{ClO}$ depletion took place. This confirms that $\mathrm{HOCl}$ is the main active chlorine species produced by proton forcing under nighttime conditions. Lower $\mathrm{HOCl}$ changes ( $\sim 0.1 \mathrm{ppbv})$ have been detected at illuminated latitudes. There, SPE-induced active chlorine is present in the form of enhanced $\mathrm{HOCl}$ and $\mathrm{ClO}$.

WACCM4 generally reproduces the SPE-induced variability in the chorine species. Some differences in the geographic distribution of these changes arise from the underestimation of latitudinal redistribution above about $2 \mathrm{hPa}$. $\mathrm{ClO}$ decreases are reproduced quite well at high latitudes, whereas the $\mathrm{ClO}$ enhancements in the terminator region are underestimated. Moreover, contrary to our expectations, WACCM4 perturbed and base simulations indicate that this $\mathrm{ClO}$ increase is not due to SPEs. $\mathrm{HOCl}$ variations are modelled very well with respect to both magnitude and geographic distribution. WACCM4 also reproduces quite well the $\mathrm{HCl}$ depletion in the mesosphere (above $\sim 1.5 \mathrm{hPa}$ ) but underestimates or does not show the observed decrease between 1.5 and $4 \mathrm{hPa}$. $\mathrm{ClONO}_{2}$ changes observed by MIPAS have also been examined. An increase of $0.2 \mathrm{ppbv}$ around $1 \mathrm{hPa}$ in the week after the SPE occurrence has been shown. WACCM4 simulations with and without proton forcing indicate that this increase is dominated by background variability, although SPE-induced production might contribute by $0.1 \mathrm{ppbv}$.

The most striking differences between satellite data and modelling results are (i) the underestimation of the $\mathrm{HCl}$ depletion mainly below $1.5 \mathrm{hPa}$ and (ii) the lack of enhanced $\mathrm{ClO}$ in the terminator region in the WCCM4 simulations.

The difficulties encountered by Winkler et al. (2011) in reproducing the $\mathrm{HCl}$ depletion in stratosphere have been confirmed. This model-data discrepancy suggests that deficiencies in chemical schemes involving chlorine species in the upper stratosphere could be present. However the possible background variation highlighted in Figs. 4 and 5 could also contribute to explain the $\mathrm{HCl}$ discrepancies. Despite 
the lack of ion chemistry, WACCM4 reproduces (underestimates) mesospheric $\mathrm{HCl}$ changes induced by the SPE of 17 January at latitudes higher (lower) than $70^{\circ} \mathrm{N}$. Since lateral mixing is probably underestimated by WACCM4, the realistic reproduction of $\mathrm{HCl}$ concentrations at higher latitudes may be the result of compensating errors i.e., too little depletion, caused by the lack of ion chemistry, plus too little mixing. Therefore we cannot exclude the importance of the ion chemistry in the mesosphere. Addition investigations, taking into account the energetic electrons ionization, are necessary. Mesospheric $\mathrm{HCl}$ changes induced by the SPE of 20 January appear to be slightly overestimated at higher latitudes. Since a prior work (Verronen et al., 2011a) highlighted the importance of the mesospheric horizontal mixing on 21 January, this is a further element suggesting that lateral mixing could be underestimated in WACCM4 during this period.

The chlorine activation under the SPEs of January 2005 has been shown. In addition, an $\mathrm{HOCl}$ enhancement accompanied by a similar decrease in $\mathrm{HCl}$ was observed by MLS also during the SPEs of December 2006 (i.e., under similar seasonal conditions), further corroborating the hypothesis of chlorine activation under SPEs. Hints for a deactivation later after the SPEs of January 2005 have also been highlighted; however, WACCM4 did not fully reproduce this, so no clear conclusions can be drawn. More accurate simulations of $\mathrm{HO}_{\mathrm{x}}$ under SPE conditions (Funke et al., 2011; Jackman et al., 2011) could clarify these model-data differences in $\mathrm{ClO}$ in the the terminator.

In general, WACCM4 simulations reproduce better the impact of SPEs on chlorine species for the January 2005 SPE than for the 2003 Halloween storm (Funke et al., 2011). The major reason for this difference is that the vortex was well established, coincident with the terminator, in January 2005, while the early winter vortex in October 2003 was partially illuminated. However, also during January 2005, the WACCM4 simulations did not fully capture all the measured changes and future work will be necessary to understand and remove remaining minor model-data inconsistencies.

Acknowledgements. This work was supported by FONDECYT project no. 3110159 and CONICYT ANILLO Preis ACT98. The IAA team was supported by the Spanish MICINN under project AYA2008-03498/ESP, project 200950I081 of CSIC, and EC FEDER funds. WACCM simulations were performed at the National Center for Atmospheric Research (NCAR). NCAR is supported by the National Science Foundation. Support for DRM was provided by the National Aeronautics and Space Administration grant NNX08AX28G. Support for CHJ was provided by the NASA Living With a Star Targeted Research and Technology Program. Work at the Jet Propulsion Laboratory, California Institute of Technology, was done under contract with the National Aeronautics and Space Administration. MS was supported by Italian Space Agency under contract no. I/022/10/0.

Edited by: A. J. G. Baumgaertner

\section{References}

Becker, E. and von Savigny, C.: Dynamical heating of the polar summer mesopause induced by solar proton events, J. Geophys. Res.,115, D00I18, doi:10.1029/2009JD012561, 2010.

Chshyolkova, T., Manson, A. H., Meek, C. E., Aso, T., Avery, S. K., Hall, C. M., Hocking, W., Igarashi, K., Jacobi, C., Makarov, N., Mitchell, N., Murayama, Y., Singer, W., Thorsen, D., and Tsutsumi, M.: Polar vortex evolution during Northern Hemispheric winter 2004/05, Ann. Geophys., 25, 1279-1298, doi:10.5194/angeo-25-1279-2007, 2007.

von Clarmann, T., Glatthor, N., Grabowski, U., Höpfner, M., Kellmann, S., Kiefer, M., Linden, A., Mengistu Tsidu, G., Milz, M., Steck, T., Stiller, G. P., Wang, D. Y., Fischer, H., Funke, B., Gil-López, S., and López-Puertas, M.: Retrieval of temperature and tangent altitude pointing from limb emission spectra recorded from space by the Michelson Interferometer for Passive Atmospheric Sounding (MIPAS), J. Geophys. Res., 108, 4736, doi:10.1029/2003JD003602, 2003.

von Clarmann, T., Glatthor, N., Höpfner, M., Kellmann, S., Ruhnke, R., Stiller, G. P., Fischer, H., Funke, B., GilLópez, S., and López-Puertas, M.: Experimental evidence of perturbed odd hydrogen and chlorine chemistry after the October 2003 solar proton events, J. Geophys. Res., 110, A09S45, doi:10.1029/2005JA011053, 2005.

von Clarmann, T., Höpfner, M., Kellmann, S., Linden, A., Chauhan, S., Funke, B., Grabowski, U., Glatthor, N., Kiefer, M., Schieferdecker, T., Stiller, G. P., and Versick, S.: Retrieval of temperature, $\mathrm{H}_{2} \mathrm{O}, \mathrm{O}_{3}, \mathrm{HNO}_{3}, \mathrm{CH}_{4}, \mathrm{~N}_{2} \mathrm{O}, \mathrm{ClONO}_{2}$ and $\mathrm{ClO}$ from MIPAS reduced resolution nominal mode limb emission measurements, Atmos. Meas. Tech., 2, 159-175, doi:10.5194/amt-2-159-2009, 2009a.

von Clarmann, T., Glatthor, N., Ruhnke, R., Stiller, G. P., Kirner, O., Reddmann, T., Höpfner, M., Kellmann, S., Kouker, W., Linden, A., and Funke, B.: HOCl chemistry in the Antarctic Stratospheric Vortex 2002, as observed with the Michelson Interferometer for Passive Atmospheric Sounding (MIPAS), Atmos. Chem. Phys., 9, 1817-1829, doi:10.5194/acp-9-1817-2009, $2009 \mathrm{~b}$.

Crutzen, P. J., Isaaksen, I. S., and Reid, G. C.: Solar proton events: Stratospheric sources of nitric oxide, Science, 189, 4201, 457459, 1975.

Damiani, A., Storini, M., Laurenza, M., and Rafanelli, C.: Solar particle effects on minor components of the Polar atmosphere, Ann. Geophys., 26, 361-370, doi:10.5194/angeo-26-361-2008, 2008.

Damiani, A., Diego, P., Laurenza, M., Storini, M., and Rafanelli, C.: Ozone variability related to SEP events occurring during solar cycle no 23, Adv. Space Res., 43, 28-40, 2009.

Damiani, A., Storini, M., Rafanelli, C., Diego, P.: The hydroxyl radical as an indicator of SEP fluxes in the high-latitude terrestrial atmosphere Adv. Space Res., 46, 1225-1235, 2010a.

Damiani, A., Storini, M., Santee, M. L., and Wang, S.: Variability of the nighttime $\mathrm{OH}$ layer and mesospheric ozone at high latitudes during northern winter: influence of meteorology, Atmos. Chem. Phys., 10, 10291-10303, doi:10.5194/acp10-10291-2010, 2010b.

Egorova, T., Rozanov, E., Ozolin, Y., Shapiro, A., Calisto, M., Peter, Th., Schmutz, W.: The atmospheric effects of October 2003 solar proton event simulated with the chemistry-climate model SOCOL using complete and parameterized ion chemistry, J. At- 
mos. Sol.-Terr. Phy., 73, 356-365, 2011.

El Amraoui, L., Semane, N., Peuch, V.-H., and Santee, M. L.: Investigation of dynamical processes in the polar stratospheric vortex during the unusually cold winter 2004/2005, Geophys. Res. Lett., 35, L03803, doi:10.1029/2007GL031251, 2008.

Fischer, H., Birk, M., Blom, C., Carli, B., Carlotti, M., von Clarmann, T., Delbouille, L., Dudhia, A., Ehhalt, D., Endemann, M., Flaud, J. M., Gessner, R., Kleinert, A., Koopman, R., Langen, J., López-Puertas, M., Mosner, P., Nett, H., Oelhaf, H., Perron, G., Remedios, J., Ridolfi, M., Stiller, G., and Zander, R.: MIPAS: an instrument for atmospheric and climate research, Atmos. Chem. Phys., 8, 2151-2188, doi:10.5194/acp-8-2151-2008, 2008.

Froidevaux, L., Livesey, N. J., Read, W. G., Salawitch, R. J., Waters, J. W., Drouin, B. J., MacKenzie, I. A., Pumphrey, H. C., Bernath, P., Boone, C., Nassar, R., Montzka, S., Elkins, J., Cunnold, D., and Waugh, D.: Temporal decrease in upper atmospheric chlorine, Geophys. Res. Lett., 33, L23812, doi:10.1029/2006GL027600, 2006.

Froidevaux, L., Jiang, Y. B., Lambert, A., Livesey, N. J., Read, W. G., Waters, J. W., Fuller, R. A., Marcy, T. P., Popp, P. J., Gao, R. S., Fahey, D. W., Jucks, K. W., Stachnik, R. A., Toon, G. C., Christensen, L .E., Webster, C. R., Bernath, P. F., Boone, C. D., Walker, K .A., Pumphrey, H. C., Harwood, R. S., Manney, G. L., Schwartz, M. J., Daffer, W. H., Drouin, B. J., Cofield, R. E., Cuddy, D. T., Jarnot, R. F., Knosp, B. W., Perun, V. S., Snyder, W. V., Stek, P. C., Thurstans, R. P., and Wagner, P. A.: Validation of Aura Microwave Limb Sounder HCl measurements, J. Geophys. Res., 113, D15S25, doi:10.1029/ 2007JD009025, 2008.

Funke, B., Baumgaertner, A., Calisto, M., Egorova, T., Jackman, C. H., Kieser, J., Krivolutsky, A., López-Puertas, M., Marsh, D. R., Reddmann, T., Rozanov, E., Salmi, S.-M., Sinnhuber, M., Stiller, G. P., Verronen, P. T., Versick, S., von Clarmann, T., Vyushkova, T. Y., Wieters, N., and Wissing, J. M.: Composition changes after the "Halloween" solar proton event: the High Energy Particle Precipitation in the Atmosphere (HEPPA) model versus MIPAS data intercomparison study, Atmos. Chem. Phys., 11, 9089-9139, doi:10.5194/acp-11-90892011, 2011.

Höpfner, M., von Clarmann, T., Fischer, H., Funke, B., Glatthor, N., Grabowski, U., Kellmann, S., Kiefer, M., Linden, A., Milz, M., Steck, T., Stiller, G. P., Bernath, P., Blom, C. E., Blumenstock, Th., Boone, C., Chance, K., Coffey, M. T., FriedlVallon, F., Griffith, D., Hannigan, J. W., Hase, F., Jones, N., Jucks, K. W., Keim, C., Kleinert, A., Kouker, W., Liu, G. Y., Mahieu, E., Mellqvist, J., Mikuteit, S., Notholt, J., Oelhaf, H., Piesch, C., Reddmann, T., Ruhnke, R., Schneider, M., Strandberg, A., Toon, G., Walker, K. A., Warneke, T., Wetzel, G., Wood, S., and Zander, R.: Validation of MIPAS $\mathrm{ClONO}_{2}$ measurements, Atmos. Chem. Phys., 7, 257-281, doi:10.5194/acp-7257-2007, 2007.

Jackman, C. H., Frederick, J. E., and Stolarski, R. S.: Production of odd nitrogen in the stratosphere and mesosphere: an intercomparison of source strengths, J. Geophys. Res., 85, 7495-7505, 1980.

Jackman, C. H., DeLand, M. T., Labow, G. J., Fleming, E. L., Weisenstein, D. K., Ko, M. K. W., Sinnhuber, M., and Russell, J. M.: Neutral atmospheric influences of the solar proton events in October-November 2003, J. Geophys. Res., 110,
A09S27, doi:10.1029/2004JA010888, 2005.

Jackman, C. H., Marsh, D. R., Vitt, F. M., Garcia, R. R., Fleming, E. L., Labow, G. J., Randall, C. E., López-Puertas, M., Funke, B., von Clarmann, T., and Stiller, G. P.: Shortand medium-term atmospheric constituent effects of very large solar proton events, Atmos. Chem. Phys., 8, 765-785, doi:10.5194/acp-8-765-2008, 2008.

Jackman, C. H., Marsh, D. R., Vitt, F. M., Garcia, R. R., Randall, C. E., Fleming, E. L., and Frith, S. M.: Long-term middle atmosphere influence of very large solar proton events, J. Geophys. Res., 114, D11304, doi:10.1029/2008JD011415, 2009.

Jackman, C. H., Marsh, D. R., Vitt, F. M., Roble, R. G., Randall, C. E., Bernath, P. F., Funke, B., López-Puertas, M., Versick, S., Stiller, G. P., Tylka, A. J., and Fleming, E. L.: Northern Hemisphere atmospheric influence of the solar proton events and ground level enhancement in January 2005, Atmos. Chem. Phys., 11, 6153-6166, doi:10.5194/acp-11-6153-2011, 2011.

Jones, A., Urban, J., Murtagh, D. P., Sanchez, C., Walker, K. A., Livesey, N. J., Froidevaux, L., and Santee, M. L.: Analysis of $\mathrm{HCl}$ and $\mathrm{ClO}$ time series in the upper stratosphere using satellite data sets, Atmos. Chem. Phys., 11, 5321-5333, doi:10.5194/acp11-5321-2011, 2011.

Klekociuk, A. R., Bombardieri, D. J., Duldig, M. L., and Michael, K. J.: Atmospheric chemistry effects of the 20 January 2005 solar proton event, Adv. Geosci., 14, 305-319, 2007, http://www.adv-geosci.net/14/305/2007/.

Kovalenko, L. J., Jucks, K. W., Salawitch, R. J., Toon, G. C., Blavier, J.-F., Johnson, D. G., Kleinböhl, A., Livesey, N. J., Margitan, J. J., Pickett, H. M., Santee, M. L., Sen, B., Stachnik, R. A., and Waters, J. W.: Observed and modeled $\mathrm{HOCl}$ profiles in the midlatitude stratosphere: implication for ozone loss, Geophys. Res. Lett., 34, L19801, doi:10.1029/2007GL031100, 2007.

Lambert, A., Read, W. G., Livesey, N. J., Santee, M. L., Manney, G. L., Froidevaux, L., Wu, D. L., Schwartz, M. J., Pumphrey, H. C., Jimenez, C., Nedoluha, G. E., Cofield, R. E., Cuddy, D. T., Daffer, W. H., Drouin, B. J., Fuller, R. A., Jarnot, R. F., Knosp, B. W., Pickett, H. M., Perun, V. S., Snyder, W. V., Stek, P. C., Thurstans, R. P., Wagner, P. A., Waters, J. W., Jucks, K. W., Toon, G. C., Stachnik, R. A., Bernath, P. F., Boone, C. D., Walker, K. A., Urban, J., Murtagh, D., Elkins, J. W., and Atlas, E.: Validation of the Aura Microwave Limb Sounder middle atmosphere water vapor and nitrous oxide measurements, J. Geophys. Res., 112, D24S36, doi:10.1029/2007JD008724, 2007.

Lary, D.: Catalytic destruction of stratospheric ozone, J. Geophys. Res., 102, 21515-21526, 1997.

Lipson, J. B., Elrod, M. J., Beiderhase, T. W., Molina, L. T., and Molina, M. J.: Temperature dependence of the rate constant and branching ratio for the $\mathrm{OH}+\mathrm{ClO}$ reaction, J. Chem. Soc. Faraday T., 93, 2665-2673, 1997.

Livesey, N. J., Read, W. G., Lambert, A., Cofield, R. E., Cuddy, D. T., Froidevaux, L., Fuller, R. A., Jarnot, R. F., Jiang, J. H., Jiang, Y. B., Knosp, B. W., Kovalenko, L. J., Pickett, H. M., Pumphrey, H. C., Santee, M. L., Schwartz, M. J., Stek, P. C., Wagner, P. A., Waters, J. W., and Wu, D. L.: Earth Observing System (EOS) Microwave Limb Sounder (MLS) Version 2.2 Level 2 data quality and description document, Report JPL D-33509, Version 2.2x1.0a, Jet Propulsion Laboratory, California Institute of Technology, Pasadena, CA, USA, 2007. 
Livesey, N. J., Read, W. G., Froidevaux, L., Lambert, A., Manney, G. L., Pumphrey, H. C., Santee, M. L., Schwartz, M. J., Wang, S., Cofield, R. E., Cuddy, D. T., Fuller, R. A., Jarnot, R. F., Jiang, J. H., Knosp, B. W., Stek, P. C., Wagner, P. A., and Wu, D. L: Earth Observing System (EOS) Microwave Limb Sounder (MLS) Version 3.3 Level 2 data quality and description document, Report JPL D-33509, Version 3.3x-1.0, Jet Propulsion Laboratory, California Institute of Technology, Pasadena, CA, USA, 2011.

López-Puertas, M., Funke, B., Gil-López, S., von Clarmann, T., Stiller, G. P., Höpfner, M., Kellmann, S., Mengistu Tsidu, G., Fischer, H., and Jackman, C. H.: $\mathrm{HNO}_{3}, \mathrm{~N}_{2} \mathrm{O}_{5}$, and $\mathrm{ClONO}_{2}$ enhancements after the October-November 2003 solar proton events, J. Geophys. Res., 110, A09S44, doi:10.1029/2005JA011051, 2005a.

López-Puertas, M., Funke, B., Gil-López, S., von Clarmann, T., Stiller, G. P., Höpfner, M., Kellmann, S., Fischer, H., and Jackman, C. H.: Observation of $\mathrm{NO}_{\mathrm{x}}$ enhancement and ozone depletion in the Northern and Southern Hemispheres after the October-November 2003 solar proton events, J. Geophys. Res., 110, A09S43, doi:10.1029/2005JA011050, 2005b.

Manney, G. L., Santee, M. L., Froidevaux, L., Hoppel, K., Livesey, N. J., and Waters, J. W.: EOS MLS observations of ozone loss in the 2004-2005 Arctic winter, Geophys. Res. Lett., 33, L04802, doi:10.1029/2005GL024494, 2006.

Manney, G. L., Schwartz, M. J., Krüger, K., Santee, M. L., Pawson, S., Lee, J. N., Daffer, W. H., Fuller, R. A., and Livesey, N. J.: Aura Microwave Limb Sounder observations of dynamics and transport during the record-breaking 2009 Arctic stratospheric major warming, Geophys. Res. Lett., 36, L12815, doi:10.1029/2009GL038586, 2009.

Marsh, D.: Chemical-dynamical coupling in the mesosphere and lower thermosphere, in Aeronomy of the Earth's Atmosphere and Ionosphere, IAGA Special Sopron Book Ser., vol. 2, 1st ed., edited by: Abdu, M., Pancheva, D., and Bhattacharyya, A., Springer, Dordrecht, The Netherlands, doi:10.1007/978-94-0070326-1_1, 2011.

Orsolini, Y. J., Urban, J., and Murtagh, D. P.: Nitric acid in the stratosphere based on Odin observations from 2001 to 2009 Part 2: High-altitude polar enhancements, Atmos. Chem. Phys., 9, 7045-7052, doi:10.5194/acp-9-7045-2009, 2009.

Pickett, H. M., Drouin, B. J., Canty, T., Salawitch, R. J., Fuller, R. A., Perun, V. S., Livesey, N. J., Waters, J. W., Stachnik, R. A., Sander, S. P., Traub, W. A., Jucks, K. W., and Minschwaner, K.: Validation of Aura Microwave Limb Sounder $\mathrm{OH}$ and $\mathrm{HO}_{2}$ measurements, J. Geophys. Res., 113, D16S30, doi:10.1029/2007JD008775, 2008.

Randall, C. E., Harvey, V. L., Manney, G. L., Orsolini, Y. J., Codrescu, M., Sioris, C., Brohede, S., Haley, C. S., Gordley, L. L., Zawodny, J. M., and Russell III, J. M. Stratospheric effects of energetic particle precipitation in 2003-2004, Geophys. Res. Lett., 32, L05802, doi:10.1029/2004GL022003, 2005.

Rohen, G. J., von Savigny, C., Sinnhuber, M., Llewellyn, E. J., Kaiser, J. W., Jackman, C. H., Kallenrode, M.-B., Schröter, J., Eichmann, K.-U., Bovensmann, H., and Burrows, J. P.: Ozone depletion during the solar proton events of October/November 2003 as seen by SCIAMACHY, J. Geophys. Res., 110, A09S39, doi:10.1029/2004JA010984, 2005.

Salmi, S.-M., Verronen, P. T., Thölix, L., Kyrölä, E., Backman, L., Karpechko, A. Yu., and Seppälä, A.: Mesosphere-to-stratosphere descent of odd nitrogen in February-March 2009 after sudden stratospheric warming, Atmos. Chem. Phys., 11, 4645-4655, doi:10.5194/acp-11-4645-2011, 2011.

Sander, S. P., Friedl, R. R., Ravishankara, A. R., Golden, D. M., Kolb, C. E., Kurylo, M. J., Molina, M. J., Moortgat, G. K., KellerRudek, H., Finlayson-Pitts, B. J., Wine, P., Huie, R. E., and Orkin, V. L.: Chemical kinetics and Photochemical Data for the Use in Atmospheric Studies, Evaluation Number 15, JPL publication 06-2, Jet Propulsion Laboratory, California Institute of Technology, Pasadena, CA, USA, 2006.

Sander, S. P., Abbatt, J., Barker, J. R., Burkholder, J. B., Friedl, R. R., Golden, D. M., Huie, R. E., Kolb, C. E., Kurylo, M. J., Moortgat, G. K., Orkin, V. L., and Wine, P. H.: Chemical kinetics and Photochemical Data for the Use in Atmospheric Studies, Evaluation Number 17, JPL publication 10-6, Jet Propulsion Laboratory, California Institute of Technology, Pasadena, CA, USA, 2011.

Santee, M. L., Lambert, A., Read, W. G., Livesey, N. J., Manney, G. L., Cofield, R. E., Cuddy, D. T., Daffer, W. H., Drouin, B. J., Froidevaux, L., Fuller, R. A., Jarnot, R. F., Knosp, B. W., Perun, V. S., Snyder, W. V., Stek, P. C., Thurstans, R. P., Wagner, P. A., Waters, J. W., Connor, B., Urban, J., Murtagh, D., Ricaud, P., Barret, B., Kleinbohl, A., Kuttippurath, J., Kullmann, H., von Hobe, M., Toon, G. C., and Stachnik, R. A.: Validation of the Aura Microwave Limb Sounder ClO measurements, J. Geophys. Res., 113, D15S22, doi:10.1029/2007JD008762, 2008.

Semeniuk, K., McConnell, J. C., and Jackman, C. H.: Simulation of the October-November 2003 solar proton events in the CMAM GCM: Comparison with observations, Geophys. Res. Lett., 32, L15S02, doi:10.1029/2005GL022392, 2005.

Seppälä, A., Verronen, P. T., Sofieva, V. F., Tamminen, J., Kyrölä, E., Rodger, C. J., and Clilverd, M. A.: Destruction of the tertiary ozone maximum during a solar proton event, Geophys. Res. Lett., 33, L07804, doi:10.1029/2005GL025571, 2006.

Seppälä, A., Clilverd, M. A., Rodger, C. J., Verronen, P. T., and Turunen, E.: The effects of hard-spectra solar proton events on the middle atmosphere, J. Geophys. Res., 113, A11311, doi:10.1029/2008JA013517, 2008.

Siskind, D. E., Eckermann, S. D., Coy, L., McCormack, J. P., and Randall, C. E.: On recent interannual variability of the Arctic winter mesosphere: implications for tracer descent, Geophys. Res. Lett., 34, L09806, doi:10.1029/2007GL029293, 2007.

Solomon, S. and Crutzen, P. J.: Analysis of the August 1972 solar proton event including chlorine chemistry, J. Geophys. Res., 86 (C2), 114-1146, doi:10.1029/JC086iC02p01140, 1981.

Solomon, S., Rusch, D. V., Gérard, J.-C., Reid, G. C., and Crutzen, P. J.: The effect of particle precipitation events on the neutral and ion chemistry of the middle atmosphere: II odd hydrogen, Planet. Space Sci., 29, 885-892, 1981.

Stimpfle, R. M., Perry, R. A., and Howard, C. J.: Temperaturedependence of the reaction of $\mathrm{ClO}$ and $\mathrm{HO}_{2}$ radicals, J. Chem. Phys., 71, 5183-5190, 1979.

Swider, W. and Keneshea, T. J.: Decrease of ozone and atomic oxygen in the lower mesosphere during a PCA event, Planet. Space Sci., 21, 1969-1973, 1973.

Verronen, P. T., Seppälä, A., Kyrola, E., Tamminen, J., Pickett, H M., and Turunen, E.: Production of odd hydrogen in the mesosphere during the January 2005 solar proton event, Geophys Res. Lett., 33, L24811, doi:10.1029/2006GL028115, 2006. 
Verronen, P. T., Rodger, C. J., Clilverd, M. A., Pickett, H. M., and Turunen, E.: Latitudinal extent of the January 2005 solar proton event in the Northern Hemisphere from satellite observations of hydroxyl, Ann. Geophys., 25, 2203-2215, doi:10.5194/angeo25-2203-2007, 2007.

Verronen, P. T., Santee, M. L., Manney, G., Lehmann, R., Salmi, S.M., and Seppälä, A.: Nitric acid enhancements in the mesosphere during the January 2005 and December 2006 solar proton events, J. Geophys. Res., 116, D17301, doi:10.1029/2011JD016075, 2011.

Verronen, P. T., Rodger, C. J., Clilverd, M. A., and Wang, S.: First evidence of mesospheric hydroxyl response to electron precipitation from the radiation belts, J. Geophys. Res., 116, D07307, doi:10.1029/2010JD014965, 2011.

Waters, J. W., Froidevaux, L., Harwood, R. S., Jarnot, R., Pickett, H., Read, W., Siegel, P., Cofield, R., Filipiak, M., Flower, D., Holden, J., Lau, G., Livesey, N., Manney, G., Pumphrey, H., Santee, M., Wu, D., Cuddy, D., Lay, R., Loo, M., Perun, V., Schwartz, M., Stek, P., Thurstans, R., Boyles, M., Chandra, S., Chavez, M., Chen, G.-S., Chudasama, B., Dodge, R., Fuller, R., Girard, M., Jiang, J., Jiang, Y., Knosp, B., LaBelle, R., Lam, J., Lee, K., Miller, D., Oswald, J., Patel, N., Pukala, D., Quintero, O., Scaff, D., Snyder, W., Tope, M., Wagner, P., and Walch, M.: The Earth Observing System Microwave Limb Sounder (EOS MLS) on the Aura satellite, IEEE T. Geosci. Remote, 44, 10751092, 2006.
Winkler, H., Kazeminejad, S., Sinnhuber, M., Kallenrode, M.B., and Notholt, J.: Conversion of mesospheric $\mathrm{HCl}$ into active chlorine during the solar proton event in July 2000 in the northern polar region, J. Geophys. Res., 114, D00I03, doi:10.1029/2008JD011587, 2009.

Winkler, H., Kazeminejad, S., Sinnhuber, M., Kallenrode, M.-B., and Notholt, J.: Correction to "Conversion of mesospheric $\mathrm{HCl}$ into active chlorine during the solar proton event in July 2000 in the northern polar region”, J. Geophys. Res., 116, D17303, doi:10.1029/2011JD016274, 2011.

WMO: Scientific assessment of ozone depletion: 2006, Global Ozone Research and Monitoring Project-Report No. 50, Geneva, Switzerland, 2007.

Xu, X., Manson, A. H., Meek, C. E., Chshyolkova, T., Drummond, J. R., Hall, C. M., Riggin, D. M., and Hibbins, R. E.: Vertical and interhemispheric links in the stratosphere-mesosphere as revealed by the day-to-day variability of Aura-MLS temperature data, Ann. Geophys., 27, 3387-3409, doi:10.5194/angeo27-3387-2009, 2009. 